\title{
Advanced Sorbent Development Program
}

\author{
Annual Report \\ November 1, 1994 - November 30, 1995
}

Work Performed Under Contract No.: DE-AC21-94MC31089

For

U.S. Department of Energy

Office of Fossil Energy

Federal Energy Technology Center

Morgantown Site

MASTER

P.O. Box 880

Morgantown, West Virginia 26507-0880

PROCESSED FROM BEST AVAILABLE COPY DISTRIBUTION OF THIS DOCUMENT IS UNLIMITED

Corporate Research \& Development Division

1 Research Circle

Building K1-ES 103

Schenectady, New York 12309 


\section{Disclaimer}

This report was prepared as an account of work sponsored by an agency of the United States Government. Neither the United States Government nor any agency thereof, nor any of their employees, makes any warranty, express or implied, or assumes any legal liability or responsibility for the accuracy, completeness, or usefulness of any information, apparatus, product, or process disclosed, or represents that its use would not infringe privately owned rights. Reference herein to any specific commercial product, process, or service by trade name, trademark, manufacturer, or otherwise does not necessarily constitute or imply its endorsement, recommendation, or favoring by the United States Government or any agency thereof. The views and opinions of authors expressed herein do not necessarily state or reflect those of the United States Government or any agency thereof. 


\section{DISCLAIMER}

Portions of this document may be illegible electronic image products. Images are produced from the best available original document. 


\section{INTRODUCTION}

\section{PROGRAM OBJECTIVES}

The overall objective of this program is to develop regenerable sorbents for hydrogen sulfide removal from coal-derived fuel gases in the temperature range $343-538^{\circ} \mathrm{C}\left(650-1000^{\circ} \mathrm{F}\right)$. Two categories of reactor configurations are being considered: fixed-bed/moving-bed reactors and fluidized-bed (bubbling and circulating) reactors. In addition, a cost assessment and a market plan for large-scale fabrication of sorbents will be developed. As an optional task, a long-term bench-scale testing ( 100 cycles) of the best fixed-bed/moving-bed and fluidized-bed sorbents will be conducted.

The sorbents will have chemical characteristics that permit cyclic regeneration over many cycles without a drastic loss of activity. They must also have physical characteristics that are compatible with the selected reactor, e.g., fixed vs fluidized bed, and which remain acceptable during absorption and regeneration. The sorbents must be capable of reducing the hydrogen sulfide level in the fuel gas to less than $20 \mathrm{ppmv}$ in the specified temperature range and pressures in the range of 1 to 20 atmospheres.

\section{PROJECT DESCRIPTION}

The proposed program is divided into several tasks:

Task 1 - NEPA Report

Task 2 - Sorbent Preparation

Task 3 - Provision of Bench Unit

Task 4 - Bench Testing

Task 5 - Sorbent Cost Assessment

Task 6 - Topical Report

Task 7 - Market Plan

Task 8 - Long-Term Testing (option)

In Task 1, the information required for preparation of a NEPA report by DOE will be provided. In Task 2, several sorbents suitable for fixed-, moving-, and fluidized-bed applications will be fabricated. Three classes of materials will be used: zinc-based materials (e.g., zinc titanates), advanced metal oxide (non-zinc) materials, and proprietary materials. Selection will be based on thermodynamic and laboratory evaluation of powder materials. GE-CRD, IGT, and Prof. M. Flytzani-Stephanopoulos (consultant, Tufts University) will be responsible for identifying and screening the chemical compositions of the sorbents. Pelletization (for moving/fixed beds) and granulation (for fluidized beds) will then be 
conducted on the promising materials using suitable binders and pore formers. Standard techniques (extrusion and calcination) as well as novel techniques (solution precipitation or $\mathrm{sol} / \mathrm{gel}$ formation) will be used to modify the morphology of the formed materials. GE-CRD will focus on moving/fixed-bed applications, while IGT will focus on fluidized-bed applications. Commercial sorbent and catalyst developers will pelletize or agglomerate the final formulations for bench testing according to recommendations by GE-CRD and IGT. In Task 3, the moving/fixed-bed bench reactor at GE-CRD and the fluidized-bed reactor at IGT will be refurbished for use. In Task 4 , the eight most promising sorbents that passed screening under Task 2 will be tested for ten cycles of absorption and regeneration each in the GE-CRD moving/fixed-bed bench reactor and IGT fluidized-bed reactor, and the properties of the used materials will be compared against those of the fresh sorbents. In Task 5, a sorbent cost assessment will be performed to determine costs and sensitivity of costs for raw materials, fabrication, disposal, or recycle. In Task 6, a Topical Report will be prepared summarizing the results obtained in the program. In Task 7, a Market Plan will be developed jointly with the commercial sorbent manufacturers and users to develop a strategy for commercialization, teaming/licensing approaches, and benefits to IGCC technologies.

Finally as an optional task, Task 8 will test a minimum of two formulations, one for moving/fixed-bed systems and the other for fluidized-bed systems for long-term (at least 100 cycles) durability and chemical reactivity in the corresponding bench-scale reactor configurations.

\section{Background information}

U.S. coals have a very variable sulfur content: low in the eastern (Appalachian) fields and in the western sub-bituminous deposits, and high in the mid-western basin deposits. The major reserves that are most readily accessible to industry and population centers are the midwestern coals of Illinois, Western Kentucky, Indiana, and Iowa. Unfortunately, these coals have sulfur levels that are too high for direct utilization. Therefore, sulfur removal must be accomplished prior to combustion, during combustion, or by post-combustion processing of the exhaust stream. With the ever increasing limitations on $\mathrm{SO}_{2}$ emissions, even most low sulfur coals will eventually require some treatment at sometime in their utilization. The sulfur in coal is typically about equally divided between its occurrence as the mineral component (pyrite-FeS $\mathrm{S}_{2}$ ) or as a sulfur-containing compound in the organic portion. Of these, the inorganic component is most readily removed via fine grinding, for liberation and separation via physical techniques. Current coal gasification technology relies on removal of some of the relatively easy inorganic fraction during coal cleaning (ash removal) and anticipates that the major removal will occur during or after gasification.

Coal gas desulfurization to sufficiently low levels at elevated temperatures is now recognized as crucial to efficient and economic coal utilization in Integrated Gasification-Combined Cycle (IGCC) systems. The implementation of hot coal gas desulfurization heavily relies on the development of regenerable sorbent materials that have high sulfur capacity and can efficiently remove $\mathrm{H}_{2} \mathrm{~S}$ (from several thousand ppmv levels down to a few ppmv) over many cycles of sulfidation/regeneration. Structural stability and good mechanical strength are also 
desirable features in a sorbent. Not surprisingly, only a few metal oxides can meet these stringent requirements.

The research and development for high-temperature desulfurization of fuel gases has been sponsored primarily by the Morgantown Energy Technology Center (METC) of the United States Department of Energy (U.S. DOE). Over the last decade a number of studies have been reported on high-temperature $\mathrm{H}_{2} \mathrm{~S}$ removal, primarily using various transition metal oxides as regenerable sorbents. ${ }^{1-5}$ The sorbent most intensively studied is iron oxide, which yields equilibrium $\mathrm{H}_{2} \mathrm{~S}$ concentrations in the few hundred ppm range for a composition representative of low Btu coal-derived gas and temperatures of above $500^{\circ} \mathrm{C}$. While the sulfidation kinetics of iron oxide are very good ${ }^{3}$, this sorbent cannot be used for single-stage coal gas desulfurization to reduce the $\mathrm{H}_{2} \mathrm{~S}$ content of the fuel gas down to a few ppm of sulfur.

Zinc oxide has been used as a non-regenerable sorbent in "guard beds" protecting catalyst beds from trace sulfur impurities. More recently, zinc oxide has also been investigated as a regenerable sorbent. ${ }^{4-8}$ The thermodynamic equilibrium for sulfidation of $\mathrm{ZnO}$ is quite favorable, yielding desulfurization down to a few $\mathrm{ppm}_{2} \mathrm{~S}$. The sulfidation kinetics of $\mathrm{ZnO}$, however, are much slower ${ }^{9}$ compared to those of iron oxide, and the regenerability of $\mathrm{ZnO}$ is restricted by the loss of surface area at high temperatures and the formation of zinc sulfate at low regeneration temperatures.

Reduction and sulfidation take place simultaneously when the sorbent is contacted with the hot fuel gas. Regeneration can be conducted with air or air-steam mixtures. When reaction and diffusion rates are sufficiently rapid, the sorbent sulfur capacity and the extent of desulfurization are determined by thermodynamics alone. With many sorbents, however, the rates of reaction, pore diffusion, or diffusion in the product layer, limit sorbent capacity and the extent of cleanup under practical conditions. Such is the case with some commercial $\mathrm{ZnO}$ sorbents where the reported conversions at breakthrough have been less than $20 \%$ in packed bed applications. The larger molar volume of the product solid ( $\mathrm{ZnS}=24.4 \mathrm{~cm}^{3} / \mathrm{mol}$ ) compared to that of the reactant solid $\left(\mathrm{ZnO}=14.4 \mathrm{~cm}^{3} / \mathrm{mol}\right)$ causes pore plugging, limiting access to the interior of the sorbent.

In recent years it has been shown that certain mixed oxides have superior properties compared to single oxides for hot gas cleanup. ${ }^{6-8,10-16}$ A compound of zinc and iron oxides, zinc ferrite, $\mathrm{ZnFe}_{2} \mathrm{O}_{4}$, developed by DOE/METC has reached pilot-stage (testing) for desulfurization of low-Btu gases. ${ }^{17-19}$ However, physical durability of the zinc ferrite sorbent in long-term testing appears to be inadequate for IGCC application.

Because of the apparent limitations of the zinc ferrite sorbent, many investigators have been conducting research to develop a superior mixed metal oxide sorbent. ${ }^{6-8,11-13,20-26}$

Work on zinc titanates such as $\mathrm{ZnTiO}_{3}, \mathrm{Zn}_{2} \mathrm{TiO}_{4}$, and $\mathrm{Zn}_{2} \mathrm{Ti}_{3} \mathrm{O}_{8}{ }^{6-8,24}$ has shown that titanium oxide is a better alternative to iron oxide additives in terms of the higher stability of the titanates over the ferrite compounds of zinc, and their similar sulfidation equilibria. With zinc titanates, the sulfidation temperature has been shown to extend to $700^{\circ} \mathrm{C}$ and sintering of the $\mathrm{ZnO}$ was greatly reduced. Although zinc titanate has also shown better attrition resistance than zinc ferrite in pilot tests, this sorbent also suffers gradual loss of reactivity in 
long-term cyclic operation, resulting in high fresh sorbent makeup rate to maintain the desired level of desulfurization ${ }^{27,28}$. Other mixed metal oxides such as copper-based and cobalt-based sorbents have also been investigated ${ }^{29-32}$; however, the research has been limited to laboratory-scale equipment.

Although higher temperature application offers better overall process efficiency, the stringent requirement for sulfur removal efficiency at temperatures above $538^{\circ} \mathrm{C}\left(1000^{\circ} \mathrm{F}\right)$ limits the choice of the sorbents to a few metal oxides (based on thermodynamic equilibrium), that have been shown to have other limitations as described earlier. The thermodynamic equilibria of many metal oxides significantly improve as the temperature decreases, making many metal oxide sorbents suitable for hot gas cleanup application in the temperature range of $343^{\circ}$ $538^{\circ} \mathrm{C}\left(650^{\circ}\right.$ to $\left.1000^{\circ} \mathrm{F}\right)$. Although the initial chemical reactivities of the sorbents generally decrease with decreasing temperature, the lower thermal stress incurred can lead to better sorbent reactivity after a large number of cycles, reducing the sorbent replacement cost. In general, the benefit to be gained by lower temperature application may outweigh the slight loss of efficiency due to lower temperature application, resulting in lower overall cost of electricity. However, no extensive study has been done on the development of advanced sorbents for the lower temperature application.

\section{Moving-Bed Applications}

Moving-bed systems are under development at $\mathrm{GE}^{33}$. Although the sorbent materials move slowly between the absorber and regenerator vessels, the level of deterioration at process conditions requires the material to be mechanically durable. Sorbent formulations prepared for moving-bed systems must have mechanical durability and exhibit satisfactory desulfurization kinetics at $538{ }^{\circ} \mathrm{C}\left(1000{ }^{\circ} \mathrm{F}\right)^{34}$; however, larger-scale demonstration systems such as the Tampa Electric Co.'s Polk Station will operate at lower temperatures, close to $482^{\circ} \mathrm{C}\left(800-900^{\circ} \mathrm{F}\right)$. Hence, development of sorbents with reactivity in this middle temperature range of 343 to $538^{\circ} \mathrm{C}(650-1000 \stackrel{\circ}{\circ})$ is important for moving-bed systems.

\section{Fluidized-Bed Applications}

Although the fixed-bed approach using metal oxides has been shown to reduce the $\mathrm{H}_{2} \mathrm{~S}$ content of the cleaned gas to very low levels, the operation is not continuous, it suffers from operational problems, and requires large-scale high temperature valves. To overcome these problems, US DOE has sponsored fluidized-bed as well as moving-and fixed-bed hot gas desulfurization research in recent years. The fluidized-bed approach offers advantages over the moving-and fixed-bed reactors because of its ability to control the reactor temperature during the highly exothermic regeneration step.

The key characteristic of concern in the fluidized-bed application is maintenance of the physical integrity of the sorbent during the chemical transformations associated with absorption-regeneration. Testing appears to verify that excessive attrition results primarily from the changes in composition during transformation and not from mechanical forces ${ }^{27,28}$. The extreme temperature and severe chemical conditions of air/steam regeneration are deleterious to many inorganic support materials and sorbent compounds. A sorbent suitable for fluidized-bed application must, therefore, have both good thermodynamic equilibrium and 
initial chemical reactivity in the range of $343^{\circ} \mathrm{C}-538^{\circ} \mathrm{C}$, as well as acceptable long-term physical and chemical durability with a reasonable cost of production. 


\section{PROGRAM DESCRIPTION BY TASK}

\section{Task 1 - NEPA Report}

The NEPA reports from GE-CRD and IGT were submitted to DOE as per contract requirements.

\section{Task 2 - Sorbent Preparation and Characterization}

A review of previous work available in the literature on high-temperature sorbents was performed, and results were evaluated in view of the program objectives considering that most of these previous studies concentrated in the range $1000-1300^{\circ} \mathrm{F}$ sulfidation, rather than $650-1000^{\circ} \mathrm{F}$. Consequently, some materials that were not as reactive in the upper temperature range may show reactivity enough to be competitive in the lower temperature range.

\section{Thermodynamic Calculations}

The thermodynamic $\mathrm{H}_{2} \mathrm{~S}$ equilibrium concentrations in simulated fuel gases (U-GAS and Texaco) for a number of potential metal oxides were calculated at elevated temperatures (i.e., $\left.350^{\circ}-550^{\circ} \mathrm{C}\right)$ and pressure $(20 \mathrm{bar})$. The metal oxides considered for this analysis included copper, zinc, iron, nickel, tin, cobalt, molybdenum, manganese, and tungsten. The number of moles of the fuel gas and the solid oxides were selected to correspond to $50 \%$ sorbent conversion during sulfidation. Based on the available data, certain restrictions were imposed on formation of a number of species so as to better simulate the actual environment.

The results of these analyses are presented in Figure 1 and Figure 2 for the U-GAS and Texaco fuel gases respectively, indicating that the calculated $\mathrm{H}_{2} \mathrm{~S}$ equilibrium is not significantly affected by the fuel gas composition. Furthermore, because of the lower temperature range (e.g., $350^{\circ}-550^{\circ} \mathrm{C}$ ), a large number of metal oxides are capable of reducing the $\mathrm{H}_{2} \mathrm{~S}$ level of the fuel gases to below $20 \mathrm{ppmv}$ for IGCC application. It should be noted that the $\mathrm{H}_{2} \mathrm{~S}$ equilibrium for copper oxide is the lowest (e.g., below $0.1 \mathrm{ppmv}$ ) if reduction to metallic copper is prevented while in the reduced form, metallic copper is still an acceptable candidate below $400^{\circ} \mathrm{C}$. 


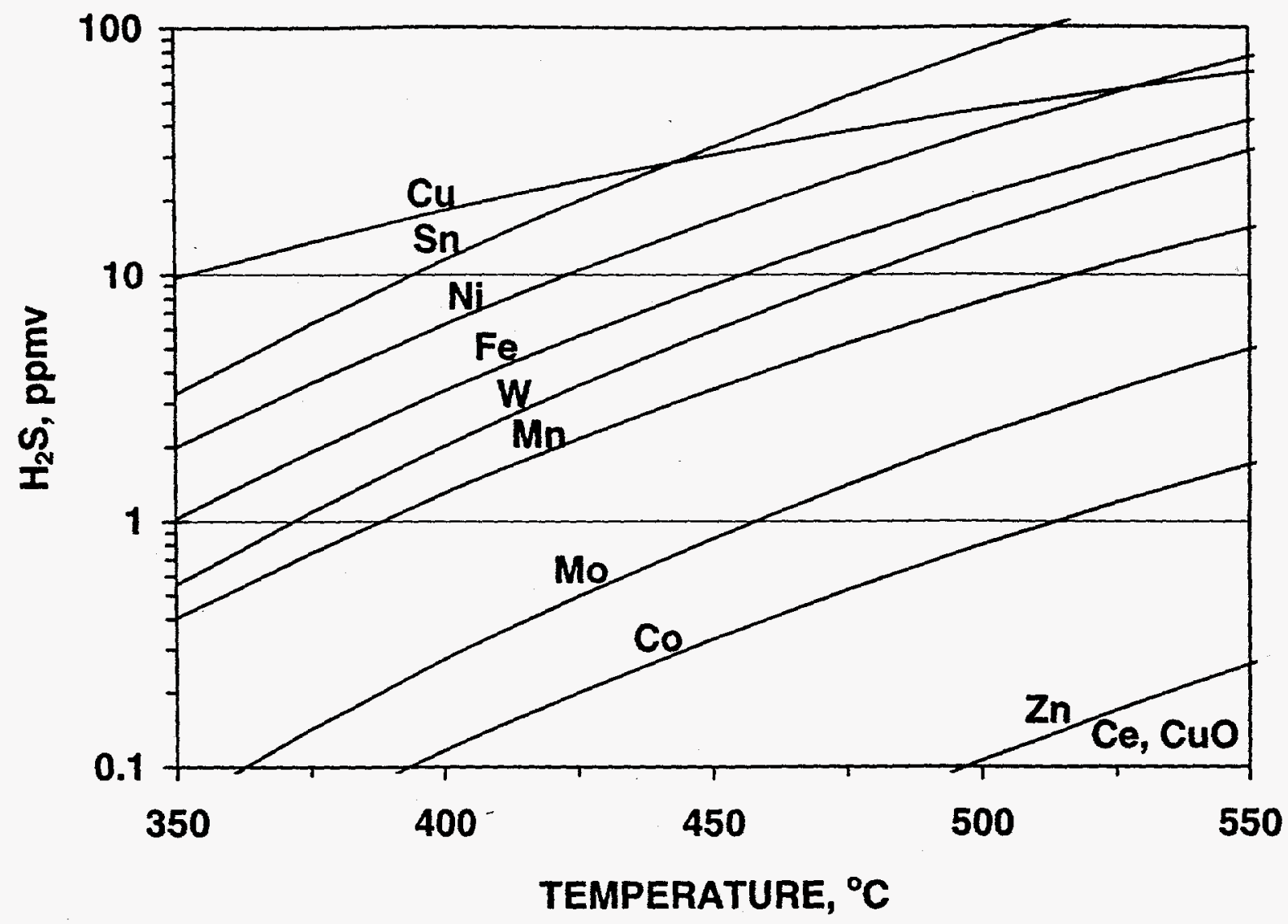

Figure 1. $\mathrm{H}_{2} \mathrm{~S}$ equilibrium concentration in fuel gas (U-GAS) with various oxides 


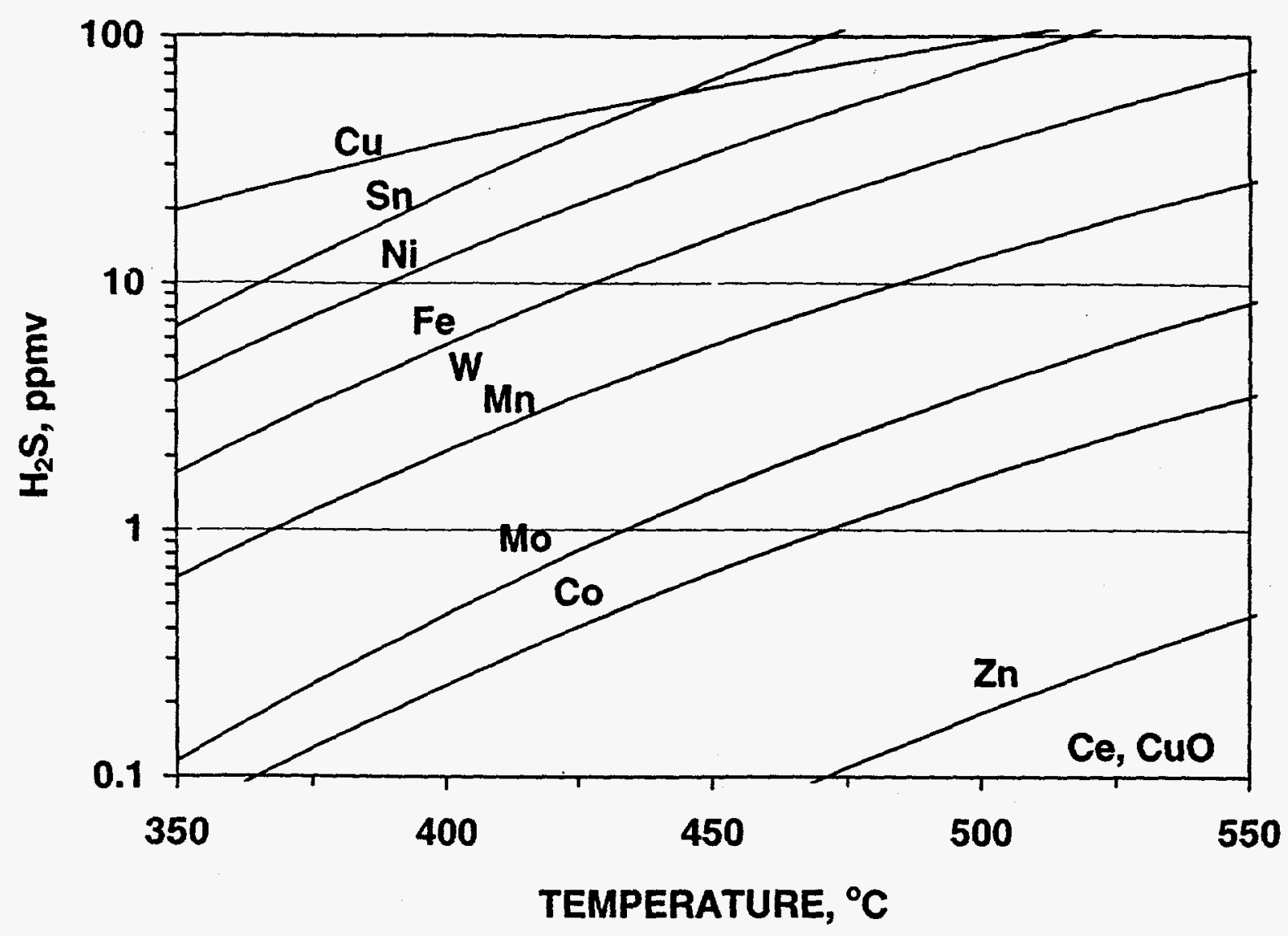

Figure 2. $\mathrm{H}_{2} \mathrm{~S}$ equilibrium concentration in fuel gas (Texaco) with various oxides

Phase stability diagrams for reducing gas atmospheres (i.e., coal gases) and oxidizing gas atmospheres (i.e., regeneration gases) have been constructed using algorithms that predict the stability of chemical species based on minimization of the Gibbs free energy of the system. The phase stability of metals under regeneration gases containing $\mathrm{SO}_{2}$ and $\mathrm{O}_{2}$ is important because spalling and pellet deterioration occurs more often as a result of metal sulfate formation. Figure 3 shows the stability of copper and molybdenum as a function of the log partial pressure of $\mathrm{O}_{2}$ and $\mathrm{SO}_{2}$. For gas compositions containing approximately 0.02 atm of $\mathrm{O}_{2}$ and 0.5 to $0.1 \mathrm{~atm} \mathrm{SO}_{2}$, (typical of atmospheric regeneration gases in the moving-bed system) the thermodynamically stable phase of copper is copper sulfate, while the thermodynamically stable form of molybdenum is the oxide. For most pure oxides, including zinc oxide, the metal sulfate is the stable form under oxidizing gas conditions at temperatures around $500-700{ }^{\circ} \mathrm{C}$, depending on $\mathrm{SO}_{2}$ and $\mathrm{O}_{2}$ concentration.

Of course, thermodynamic predictions do not take into account the rate of approach to equilibrium (i.e., kinetic rates) and hence experimental data is still needed to confirm the extent of formation of the predicted species. Nevertheless, thermodynamics allows the investigator to determine if formation of certain compounds is favored. Other phase stability diagrams are presented in Appendix A. 

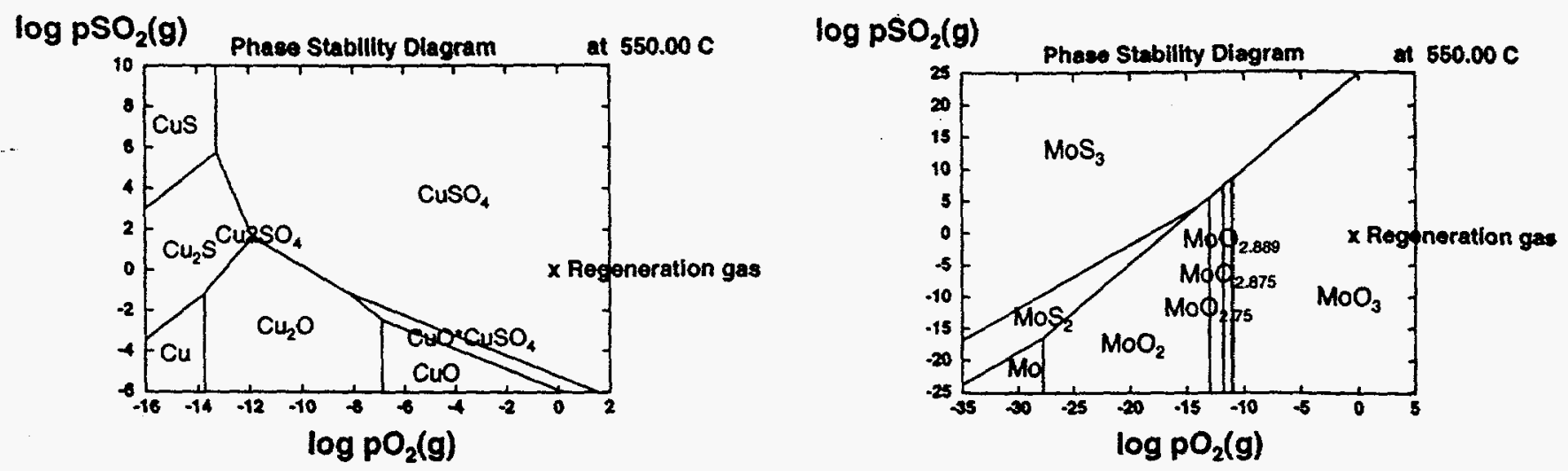

Figure 3.- Phase stability diagrams for Cu-S-O (left) and Mo-S-O (right) systems

\section{Preparation and Characterization of Sorbents for Fluidized Beds at IGT}

\section{Sorbent Screening}

A large number of sorbent formulations were prepared and tested in a fixed-bed reactor to identify the most promising sorbent formulations for high pressure fluidized-bed application in the range of $343^{\circ}-538^{\circ} \mathrm{C}$. Desirable characteristics of hot gas cleanup sorbents include:

- Favorable sulfidation equilibrium

- High sorbent capacity

- Good reactivity toward $\mathrm{H}_{2} \mathrm{~S}$

- Ease of regenerability

- Good attrition resistance

- Acceptable and stable reactivity in the cyclic process.

The initial principal criteria used for sorbent formulation was based on thermodynamic equilibrium which limits the choice of the active sorbent metals to those that can meet the stringent requirement of removing $\mathrm{H}_{2} \mathrm{~S}$ to below $20 \mathrm{ppmv}$. Although high sorbent capacity and high initial reactivity are desired, these factors are not deemed crucial in developing a sorbent that will have acceptable long-term physical and chemical durability. These factors generally translate into lower sorbent circulation rates and smaller reactor size. However, this affects the "fixed-cost" of hot gas cleanup; and does not significantly affect the overall cost of hot gas cleanup as long as certain minimum requirements (listed above) are met. The overall mechanical strength and stable reactivity of the sorbent generally affect the "variable cost" of hot gas cleanup, and are the most significant factors contributing to the overall cost of hot gas cleanup.

In a fluidized-bed hot gas cleanup process, given the cost of metal oxides, the sorbents are expected to last over a very large number (i.e., $>1000$ ) cycles. However, the reactivity of the sorbent slowly decreases in the cyclic process because of gradual physical and 
chemical deterioration. For a given reactor configuration, a minimum level of sorbent reactivity should be maintained for successful desulfurization of the fuel gas. Also, because of attrition in the fluidized bed, a certain fraction of the sorbent is generally lost or removed from the system (because of small particle size and lack of retention in the fluidized bed.) This requires that a fraction of the sorbent bed be replaced with fresh, high reactivity sorbent. Ideally, the rate of fresh makeup for maintaining sorbent reactivity should match the rate of sorbent loss due to attrition and elutriation. Therefore, these factors are the most important that should be considered during formulation of the sorbent, as long as a certain level of overall initial effective capacity can be attained.

The overall effective capacity is equal to the theoretical sorbent capacity times the sorbent conversion at breakthrough. Therefore, a sorbent with a lower theoretical capacity for sulfur but much higher reactivity may have equivalent overall effective capacity to a sorbent with higher theoretical capacity but lower reactivity. However, if the higher reactivity of a sorbent with a lower theoretical capacity can be maintained or stabilized over a very large number of cycles, then the fresh sorbent makeup rate can be reduced and therefore the overall cost of hot gas cleanup is reduced. The technique of stabilizing catalysts by the use of low metal loadings (by dispersing metal oxides with dispersants/supports, for instance) is utilized in high temperature catalyst formulations where reactivity maintenance is critical. This technique can also be applied to high temperature reactive sorbents.

Primary efforts concentrated on preparing sorbents with higher levels of reactive metal oxide dispersion that have higher and stable reactivity as well as higher mechanical strength and durability. This was accomplished by the use of refractory supports/dispersants which are themselves highly resistant to sintering and deterioration. These low theoretical capacity/highly dispersed metal oxide sorbent formulations are considered to have a higher probability for maintaining stability at elevated temperatures over a large number of sulfidation-regeneration cycles. If promising dispersed metal oxide sorbents are developed, then the next step can include increasing the metal loading (concentration) of these sorbents to obtain higher theoretical sulfur capacity. Secondary efforts included preparing sorbents with higher theoretical sulfur capacities and higher mechanical strength for fixed-bed testing at the lower temperatures of interest in this program.

\section{Sorbent Preparation}

A systematic approach was used to prepare and screen the sorbents for fixed-bed testing. Formulation parameters considered in preparing the sorbents included sorbent composition, preparation technique and induration conditions.

Sorbent compositions were first selected from the three functional groups shown in Table 1. Commercially available sorbents of similar relative compositions were also included. The dispersants/supports shown here are expected to provide adequate structural strength and sintering resistance to reduce attrition and retain the reactivity of the sorbent. 
Table 1. Relative compositions of metal oxide formulations

\begin{tabular}{c|c|c} 
Main Component & Secondary Component & Structural Component \\
\hline $\mathrm{Cu}, \mathrm{Fe}, \mathrm{Zn}, \mathrm{Mn}$ & $\mathrm{Cu}, \mathrm{Fe}, \mathrm{Mn}, \mathrm{Cr}, \mathrm{Ce}, \mathrm{Co}, \mathrm{Mo}$ & $\mathrm{TiO}_{2}, \mathrm{ZrO}_{2}$, Binders
\end{tabular}

After preparing the sorbents their mechanical strengths were compared with that of United Catalyst zinc titanate sorbent (UCI-4), considered here to be the baseline sorbent for mechanical strength. This sorbent has been shown in previous studies to have adequate attrition resistance for fluidized-bed use. If the mechanical strengths of the prepared sorbents were not at least comparable to that of the UCI zinc titanate, the sorbent formulation was modified and the above step was repeated. Formulation modification included first changing the induration conditions, followed, if necessary, by changing the preparation technique and lastly the sorbent composition.

Over 70 sorbent formulations representing various compositions, preparation techniques and induration conditions have been prepared. Of these, 17 had mechanical strength equal to or better than that of the UCI zinc titanate sorbent. These were tested in a fixedbed for $\mathrm{H}_{2} \mathrm{~S}$ removal efficiency and reactivity towards $\mathrm{H}_{2} \mathrm{~S}$.

\section{Preliminary Sulfidation-Regeneration Testing}

Preliminary sorbent testing included determination of the sulfidation reactivity and effective capacity of the sorbents prepared above to identify potential candidate sorbents for high pressure fluidized-bed application. Sorbent sulfidation-regeneration testing was carried out in a quartz fixed-bed reactor system at approximately one atmosphere pressure and temperatures of $350^{\circ}-550^{\circ} \mathrm{C}$ using a simulated coal derived-fuel gas mixture (Table 2) at a space velocity of $2000 \mathrm{hr}^{-1}$. The average particle size of the sorbents tested is approximately 550 micron. Sulfided sorbents were regenerated using nitrogen-air mixtures at temperatures of $650^{\circ}-750^{\circ} \mathrm{C}$. The extent of desulfurization was determined by analyzing the reactor exit gas for $\mathrm{H}_{2} \mathrm{~S}$ and $\mathrm{SO}_{2}$ with a dedicated gas chromatograph.

Table 2. Sulfidation feed gas mixture composition

\begin{tabular}{cc}
\hline Component & Composition, mol\% \\
\hline $\mathrm{H}_{2} \mathrm{~S}$ & $0.5-2$ \\
$\mathrm{H}_{2}$ & 10 \\
$\mathrm{CO}$ & 20 \\
$\mathrm{CO}_{2}$ & 10 \\
$\mathrm{H}_{2} \mathrm{O}$ & 10 \\
$\mathrm{~N}_{2}$ & $48-49.5$ \\
\hline
\end{tabular}

Table 3 summarizes the results of the fixed-bed testing of the 17 sorbents. Initial testing included two bulk copper-chromite sorbents (CuCr-1 and $\mathrm{CuCr}-2)$ and the UCI-4 sorbent which were tested at IGT and were shown (in earlier programs supported by the Illinois Clean Coal Institute and Enviropower, Inc.) to be highly efficient desulfurization sorbents 
at higher temperatures $\left(550^{\circ}-850^{\circ} \mathrm{C}\right)$. The $\mathrm{CuCr}-1$ and $\mathrm{CuCr}-2$ sorbents were previously prepared at IGT using a general method for synthesizing highly porous bulk mixed oxides. $\mathrm{CuCr}-1$, a chromium-rich and $\mathrm{CuCr}-2$, a copper-rich copper chromite, contain about $10 \%$ and $25 \%$ copper, respectively.

The results of the sulfidation testing of the CuCr-2 and UCI-4 sorbents, with higher theoretical sulfur capacities, and $\mathrm{CuCr}-1$ sorbent, with a lower theoretical capacity, demonstrate that higher metal oxide dispersion can have a highly beneficial effect on the reactivity of the sorbent

The $\mathrm{H}_{2} \mathrm{~S}$ breakthrough curves for the $\mathrm{CuCr}-1$ and $\mathrm{CuCr}-2$ sorbents are shown in Figure 4 and Figure 5. Sorbent conversion is based on the assumption that the active sulfide phase produced during sulfidation is the one that is the most thermodynamically stable (i.e., $\mathrm{Cu}_{2} \mathrm{~S}$ or $\mathrm{ZnS}$ ). Conversions greater than a value of one indicate the presence of other sulfided species. The desulfurization data for $\mathrm{CuCr}-1$ and $\mathrm{CuCr}-2$ at $750{ }^{\circ} \mathrm{C}$, obtained in a previous program, were included in these figures to extend the temperature range for comparison purposes. The prebreakthrough $\mathrm{H}_{2} \mathrm{~S}$ exit gas concentrations range from less than 1 to about $5 \mathrm{ppmv}$ and are significantly lower than those predicted for the elemental $\mathrm{Cu}-\mathrm{H}_{2} \mathrm{~S}$ equilibrium. These lower levels generally correspond to the copper oxide- $\mathrm{H}_{2} \mathrm{~S}$ equilibrium, suggesting that the copper in the compound oxide was not completely reduced to elemental copper by the fuel gas during sulfidation reaction. It is believed that this is probably due to either chemical and/or physical-mechanisms, whereby compound formation, such as surface spinels or surface adsorption, may retard the complete reduction to metallic copper.

The rate of sulfidation of sorbents in the form of compounds, such as the copper chromite spinels used here, is generally expected to be lower compared to the rate of sulfidation of pure metal oxides. However, the sharp rise in the $\mathrm{H}_{2} \mathrm{~S}$ breakthrough curves and the high sorbent conversions observed in these tests indicate that overall reaction rate involving copper chromite compound is sufficiently high at temperatures above $450^{\circ} \mathrm{C}$.

The $\mathrm{H}_{2} \mathrm{~S}$ prebreakthrough levels for the higher theoretical sulfur capacity UCI-4 sorbent (Figure 6), ranging from about 10-20 ppmv, are considerably higher than those obtained with the copper chromite sorbents. The gradually increasing $\mathrm{H}_{2} \mathrm{~S}$ prebreakthrough levels and very low sorbent conversions indicate a much lower reactivity compared to the lower capacity sorbents.

The maximum effective conversion as a function of temperature for the $\mathrm{CuCr}-1, \mathrm{CuCr}-2$ and UCI-4 sorbents is summarized in Figure 7. This parameter was determined at a target $\mathrm{H}_{2} \mathrm{~S}$ exit gas concentration of $20 \mathrm{ppmv}$. The effective maximum conversion of the $\mathrm{CuCr}$ 2 sorbent is lower than that of the $\mathrm{CuCr}-1$ sorbent throughout the entire temperature range studied, clearly indicating the beneficial effects of dispersion on enhancing reactivity. The effective conversion of the zinc titanate sorbent is lower than that of the copper chromite sorbents and decreases with decreasing temperature at about the same rate as that of the $\mathrm{CuCr}-2$ sorbent. 
Another indication of the higher reactivity of the highly dispersed copper chromite sorbent is shown in Figure 8, which shows the effect of temperature on the maximum space velocity. At $500^{\circ} \mathrm{C}$, the $\mathrm{CuCr}-1$ sorbent is capable of reducing the $\mathrm{H}_{2} \mathrm{~S}$ content of the fuel gas to below $20 \mathrm{ppmv}$ at space velocities as high as $15,000 \mathrm{hr}^{-1}$, which is significantly higher than the maximum space velocity for the $\mathrm{CuCr}-2$ and UCI- 4 sorbents.

Figure 9, which shows the effect of temperature on the maximum effective sulfur capacity, indicates that, although the chromium-rich copper chromite sorbent has a much lower theoretical sulfur capacity than that of the $\mathrm{CuCr}-2$ or $\mathrm{UCI}$ zinc titanate sorbents, it has comparable effective sulfur capacities at temperatures around $450^{\circ} \mathrm{C}$. Neither of the copper chromite sorbents appeared to have sufficient mechanical durability for fluidizedbed application so no further testing of these sorbents was undertaken.

Sufficient reactivity and mechanical strength was indicated for 10 of the sorbents tested in the first round to warrant further sulfidation-regeneration testing. The sorbents selected and results of the second cycle testing for these 10 sorbents are summarized in Table 4 . Higher levels of conversion at $\mathrm{H}_{2} \mathrm{~S}$ breakthrough approaching and in some cases surpassing $100 \%$ utilization of the sorbent were obtained for the more highly dispersed (lower theoretical sulfur capacity) sorbents at temperatures as low as $350^{\circ} \mathrm{C}$. Again, conversion in excess of $100 \%$ is attributed to formation of different forms of sulfides. 
Table 3. Summary of sorbent performance in first cycle

\begin{tabular}{|c|c|c|c|c|}
\hline & \multicolumn{2}{|c|}{$\begin{array}{c}\text { Sorbent Fractional Conversion } \\
\text { at } \mathrm{H}_{2} \mathrm{~S} \text { Breakthrough of }\end{array}$} \\
\hline Sorbent & Temp., ${ }^{\circ} \mathrm{C}$ & No. of Cycles & $20 \mathrm{ppmv}$ & $100 \mathrm{ppmv}$ \\
\hline $\mathrm{CuCr}-1$ & 350 & 1 & 0.04 & 0.07 \\
\hline $\mathrm{CuCr}-1$ & 400 & 1 & 0.40 & 0.44 \\
\hline $\mathrm{CuCr}-1$ & 450 & 1 & 0.81 & 0.83 \\
\hline $\mathrm{CuCr}-1$ & 500 & 1 & 0.87 & 0.90 \\
\hline $\mathrm{CuCr}-2$ & 350 & 1 & 0.03 & 0.03 \\
\hline $\mathrm{CuCr}-2$ & 450 & 1 & 0.21 & 0.26 \\
\hline $\mathrm{CuCr}-2$ & 500 & 1 & 0.42 & 0.47 \\
\hline UCI-4 & 475 & 1 & 0.11 & 0.15 \\
\hline $\mathrm{UCI}-4$ & 450 & 1 & 0.07 & 0.11 \\
\hline UCI-4 & 425 & 1 & 0.03 & 0.04 \\
\hline UCI-4 & 500 & 1 & 0.12 & 0.18 \\
\hline IGTSS-1 & 500 & 1 & 1.23 & 1.25 \\
\hline IGTSS-1 & 350 & 15 & 1.08 & 1.09 \\
\hline IGTSS-2 & 350 & 3 & 0.98 & 1.00 \\
\hline IGTSS-3 & 350 & 3 & 0.54 & 0.54 \\
\hline IGTSS-4 & 350 & 2 & 0.09 & 0.09 \\
\hline IGTSS-4 & 500 & 2 & 0.00 & 0.00 \\
\hline IGTSS-5 & 450 & 6 & 0.50 & \\
\hline IGTSS-5 & 350 & 1 & 0.15 & 0.01 \\
\hline IGTSS-5 & 500 & 2 & 0.81 & \\
\hline IGTSS-5 & 538 & 2 & 0.90 & \\
\hline IGTSS-6 & 350 & 10 & 0.83 & 0.86 \\
\hline IGTSS-7 & 350 & 1 & 0.00 & 0.00 \\
\hline IGTSS-8 & 450 & 1 & 0.00 & 0.00 \\
\hline IGTSS-8 & 538 & 1 & 0.00 & 0.00 \\
\hline IGTSS-9 & 350 & 1 & 0.09 & 0.09 \\
\hline IGTSS-10 & 350 & 3 & 0.86 & 0.89 \\
\hline IGTSS-11 & 450 & 13 & 1.01 & 1.08 \\
\hline IGTSS-11 & 350 & 1 & 0.53 & \\
\hline IGTSS-27 & 450 & 2 & 0.22 & 0.48 \\
\hline IGTSS-27 & 538 & 1 & & 0.83 \\
\hline IGTSS-54 & 450 & 1 & 0.00 & 0.00 \\
\hline IGTSS-54 & 538 & 1 & 0.00 & 0.00 \\
\hline IGTSS-55 & 450 & 1 & 0.00 & 0.01 \\
\hline IGTSS-55 & 538 & 3 & 0.26 & 0.26 \\
\hline IGTSS-57 & 450 & 2 & 0.12 & 0.75 \\
\hline
\end{tabular}


The sorbents that show lower conversion at breakthrough in Table 4 also have higher theoretical sulfur capacities. Some of these sorbents required higher desulfurization temperatures to reduce the $\mathrm{H}_{2} \mathrm{~S}$ in the exit gas to less than $20 \mathrm{ppmv}$.

Table 4. Summary of sorbent performance in first and second cycles

\begin{tabular}{|l|c|c|c|}
\hline \multicolumn{2}{|c|}{} & \multicolumn{2}{c|}{$\begin{array}{c}\text { Sorbent Fractional Conversion } \\
\text { at } \text { }_{2} \text { S Breakthrough of 20 ppmv }\end{array}$} \\
\hline Sorbent & $\begin{array}{c}\text { Temperature, } \\
{ }^{\circ} \mathbf{C}\end{array}$ & Cycle 1 & Cycle 2 \\
\hline IGTSS-1 & 350 & 1.08 & 1.13 \\
\hline IGTSS-2 & 350 & 0.98 & 0.12 \\
\hline IGTSS-3 & 350 & 0.54 & 0.19 \\
\hline IGTSS-5 & 450 & 0.50 & 0.15 \\
\hline IGTSS-6 & 350 & 0.83 & 0.77 \\
\hline IGTSS-10 & 350 & 0.86 & 0.03 \\
\hline IGTSS-11 & 450 & 1.00 & 0.67 \\
\hline IGTSS-27 & 450 & 0.22 & 0.18 \\
\hline IGTSS-57 & 450 & 0.12 & 0.54 \\
\hline IGTSS-55 & 538 & 0.26 & 0.30 \\
\hline
\end{tabular}

Based on the results of the second cycle testing, additional sulfidation-regeneration cycles were performed on seven of these sorbents, IGTSS-1, SS-6, SS-11, SS-57, SS-5, SS-55. The results of these tests are summarized in Figure 10-Figure 16. As indicated in Figure 10 , high levels of sorbent conversions were obtained at $350^{\circ} \mathrm{C}$ in the first 10 cycles for sorbent IGTSS-1. The $\mathrm{H}_{2} \mathrm{~S}$ breakthrough profiles for this sorbent (Figure 11) also indicate very high levels of desulfurization $\left(<10 \mathrm{ppmv} \mathrm{H}_{2} \mathrm{~S}\right)$. The very sharp rise in the $\mathrm{H}_{2} \mathrm{~S}$ breakthrough curves at high levels of sorbent utilization indicates that the reactivity of this sorbent towards $\mathrm{H}_{2} \mathrm{~S}$ is very high. IGTSS -1 is significantly more reactive at 350 ${ }^{\circ} \mathrm{C}$ than either the $\mathrm{CuCr}-1$ or zinc titanate sorbents tested. However, an examination of the sorbent after the 15 th cycle revealed that it had disintegrated which may explain the rapid decline in reactivity and conversion after the 10 th cycle.

Based on the excellent performance of IGTSS-1 during the initial 10 cycles, a stronger version of this sorbent, IGTSS-11, was formulated and tested. The sorbent conversions are relatively high and constant over the 13 cycles tested at $450^{\circ} \mathrm{C}$ as shown in Figure 12 . The $\mathrm{H}_{2} \mathrm{~S}$ breakthrough curves (Figure 13) indicate that this sorbent can reduce $\mathrm{H}_{2} \mathrm{~S}$ to below 10 ppmv. No loss of strength was observed after 13 cycles. Based on its mechanical strength and reactivity, this sorbent is considered a candidate for fluidizedbed reactor testing at $450^{\circ} \mathrm{C}$.

The conversions for sorbent IGTSS- 6 at $350^{\circ} \mathrm{C}$, shown in Figure 14, indicate a relatively stable reactivity for this sorbent over 10 cycles. The $\mathrm{H}_{2} \mathrm{~S}$ breakthrough curves for this 
sorbent (Figure 15) indicate very low $\mathrm{H}_{2} \mathrm{~S}$ prebreakthrough levels of below $5 \mathrm{ppm}$. Examination of the sorbent after the 10th cycle indicated no apparent loss of sorbent strength. The apparent loss of reactivity in some of the cycles is probably due to the changing sulfidation-regeneration conditions used during this series of tests. If this sorbent can maintain this level of conversion and maintain its mechanical strength for few additional cycles it will be considered a candidate for fluidized-bed reactor testing at $350^{\circ} \mathrm{C}$.

Fixed-bed testing was also conducted on three sorbents with higher theoretical sulfur capacities. The results are summarized in Figure 16. A total conversion of nearly $47 \%$ at breakthrough was attained with sorbent IGTSS- 57 in the second cycle at $450^{\circ} \mathrm{C}$. This increase in capacity over that seen in the first cycle is possibly due to a change in the oxidation state of the sorbent as a result of its method of preparation. IGTSS-5, also tested at $450^{\circ} \mathrm{C}$, shows a marked reduction in conversion after the first cycle, but a more stable performance in the next five cycles. IGTSS-55 indicates a conversion of about $35 \%$ after 3 cycles at a temperature of $538^{\circ} \mathrm{C}$ and is considered a candidate for fluidizedbed reactor testing at $538^{\circ} \mathrm{C}$. Additional fixed-bed testing will be conducted with each of these three sorbents.

\section{Conclusions of Sorbent testing at IGT}

This investigation has demonstrated that:

- Based on thermodynamic calculations, at $350^{\circ}-538^{\circ} \mathrm{C}$, a large number of metal oxides are capable of reducing the $\mathrm{H}_{2} \mathrm{~S}$ level of coal-derived fuel gases to below $20 \mathrm{ppmv}$ for IGCC application

- Sorbents with lower theoretical capacities for sulfur but much higher reactivities can have equivalent overall effective capacities as sorbents with higher theoretical capacities but lower reactivities.

- Three sorbents, IGTSS-6, IGTSS-11 and IGTSS-55 have been developed that have sufficient reactivity and mechanical strength for fluidized-bed reactor testing at $350^{\circ}$, $450^{\circ}$, and $538^{\circ} \mathrm{C}$, respectively.

\section{Future work at IGT}

Sorbents IGTSS-5, SS-6, SS-11, SS-55 and SS-57 will be further evaluated for other important characteristics, such as sorbent regenerability and mechanical durability, in multicycle sulfidation-regeneration tests. Secondary components may be added to enhance desulfurization reactivity, chemical stability, porosity and/or maintain mechanical durability, as needed.

Additional sorbent formulations will be prepared and further screening of metal oxide formulations in Table 1 will be performed. 
The most reactive and mechanically durable sorbent formulation will be produced in a form and quantity suitable for fluidized-bed testing in the bench-scale desulfurization test unit.

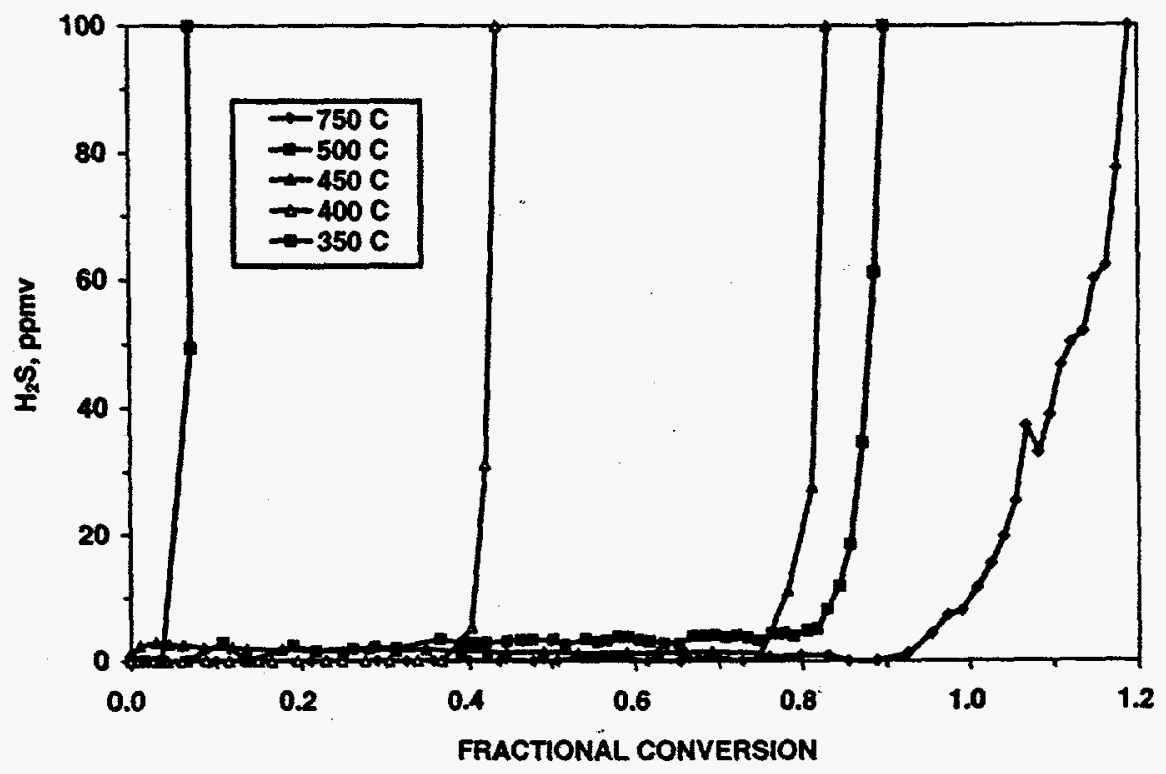

Figure 4. $\mathrm{H}_{2} \mathrm{~S}$ breakthrough curves for $\mathrm{CuCr}-1$ 


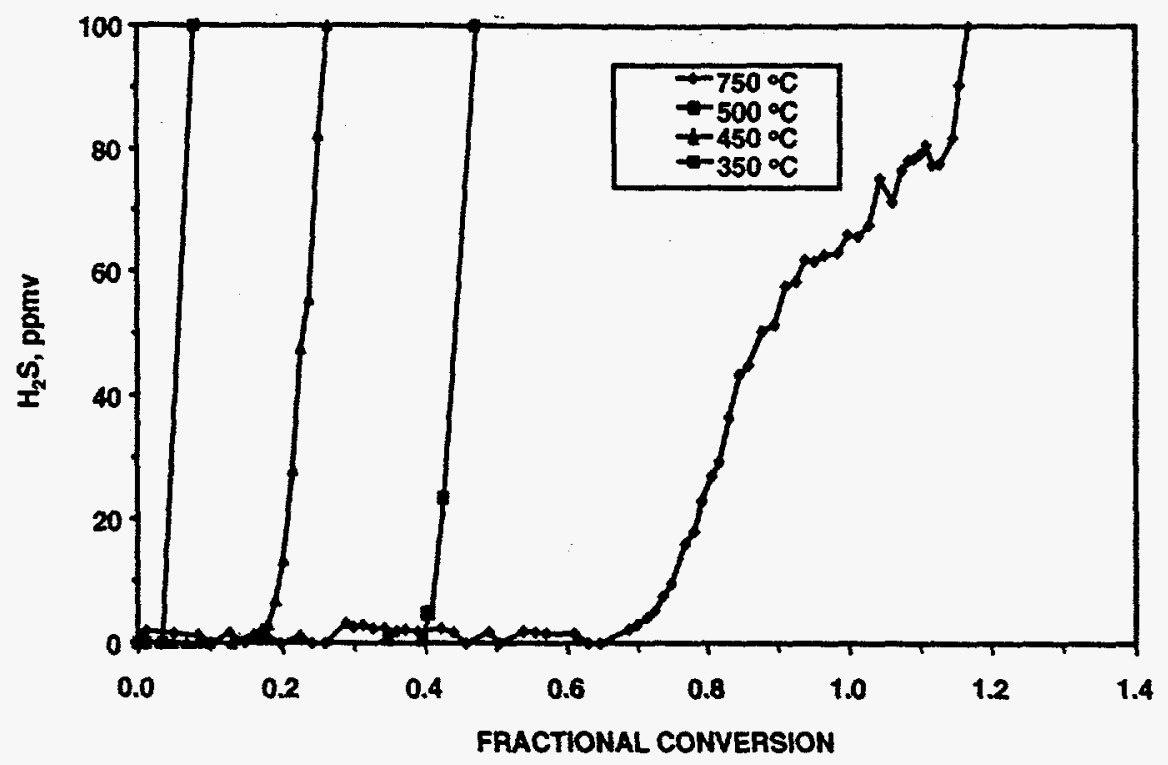

Figure 5. $\mathrm{H}_{2} \mathrm{~S}$ breakthrough curves for $\mathrm{CuCr}-2$

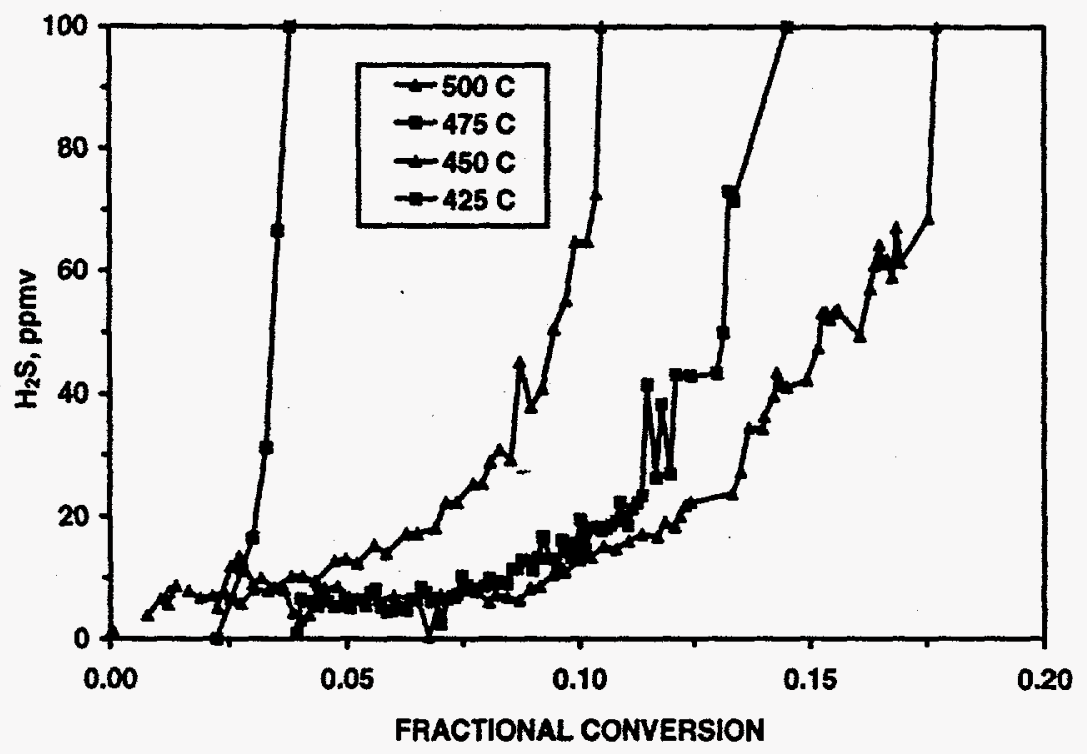

Figure 6. $\mathrm{H}_{2} \mathrm{~S}$ breakthrough curves for uci-4 zinc titanate 


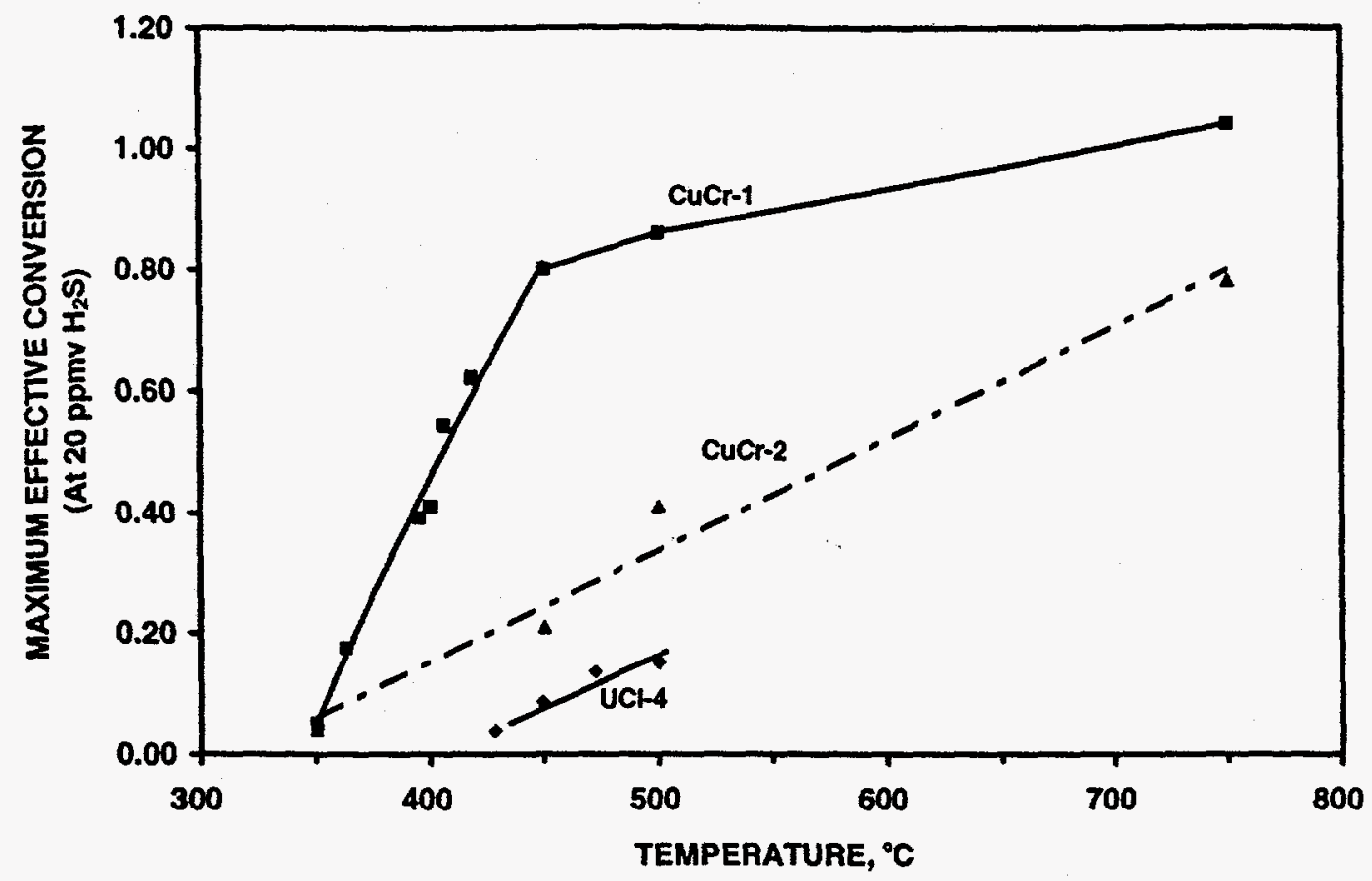

Figure 7.- Effect of temperature on effective conversion

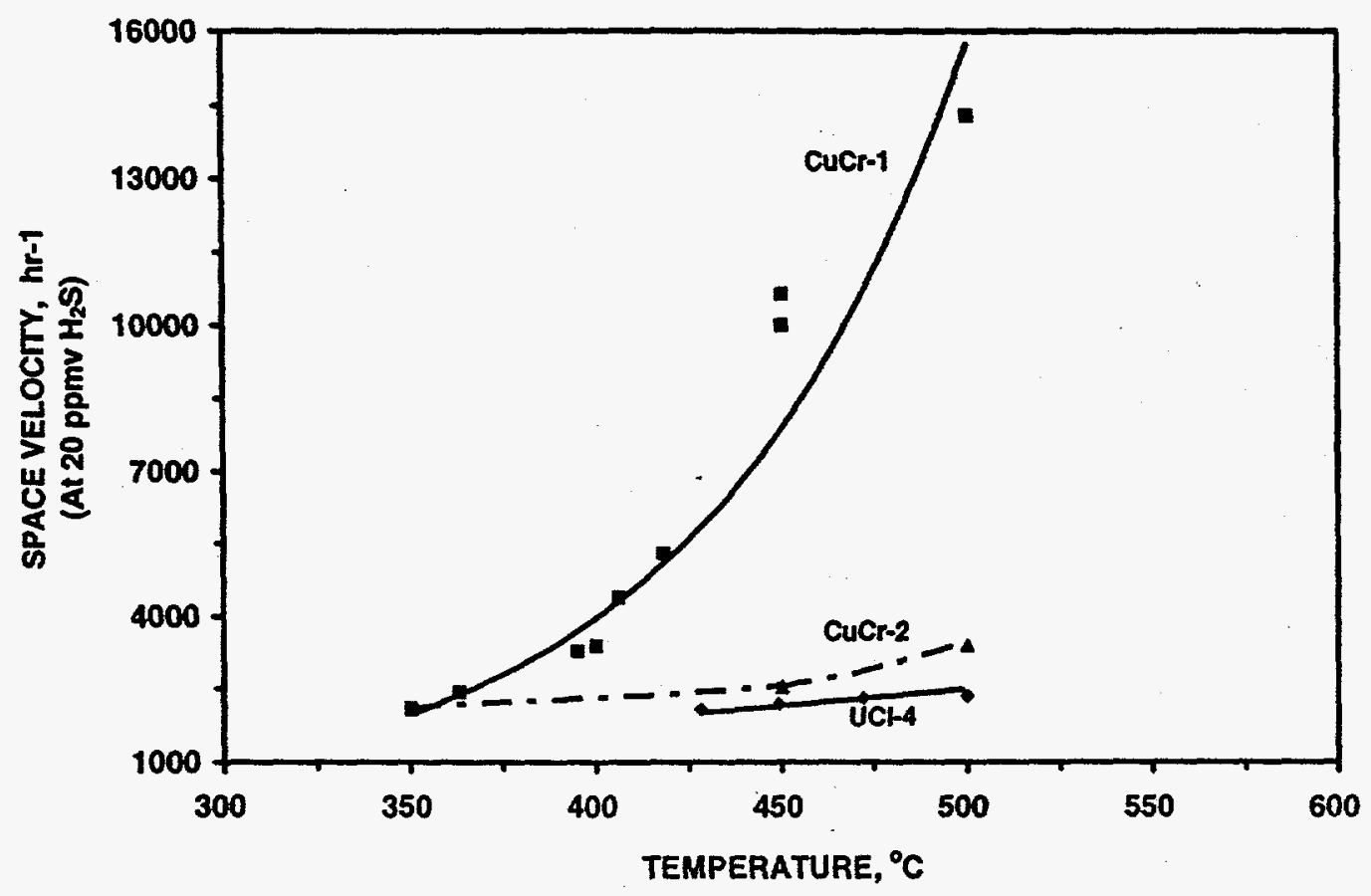

Figure 8.- Effect of temperature on maximum space velocity 


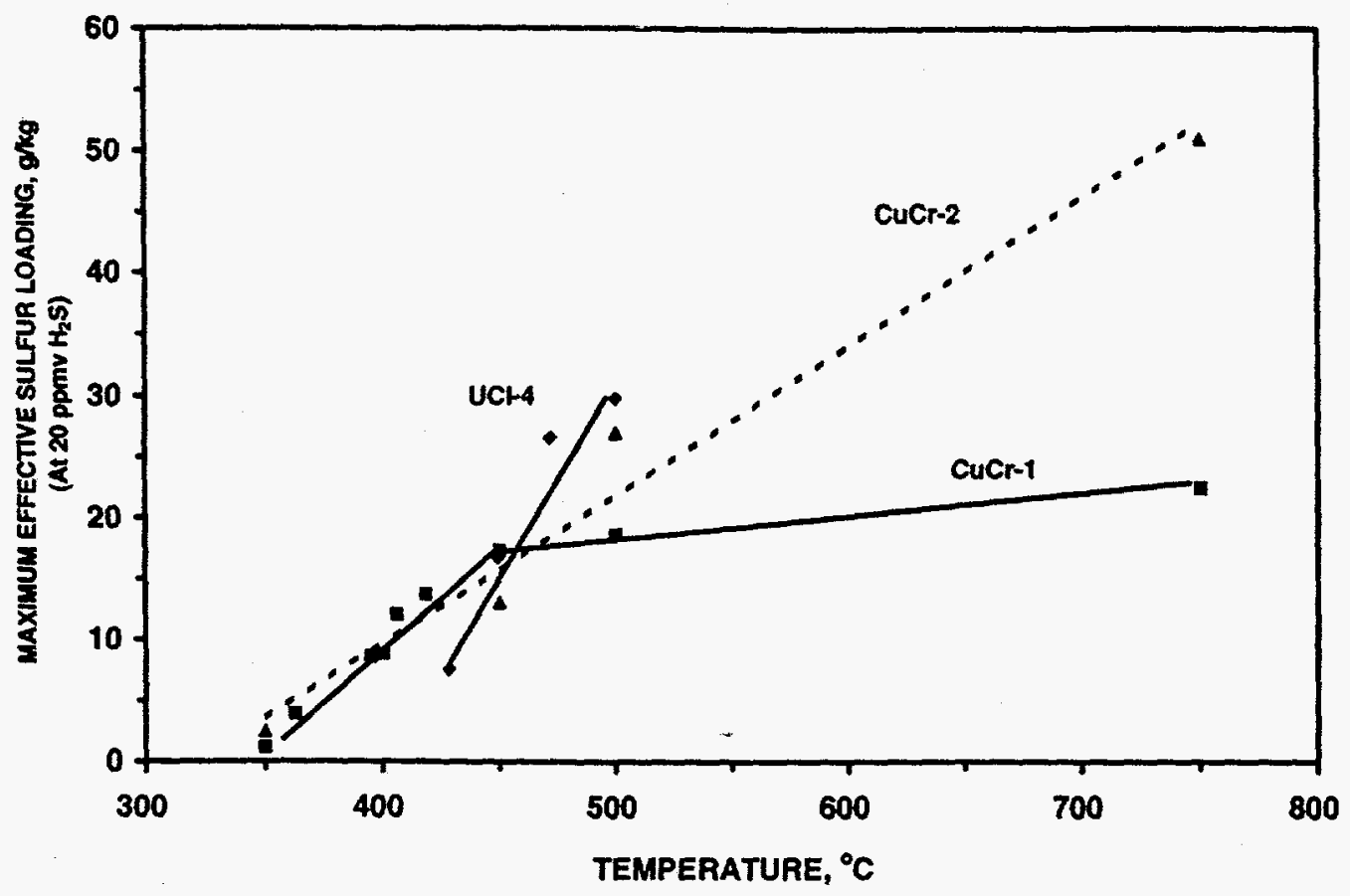

Figure 9.- Effect of temperature on maximum effective sulfur capacity

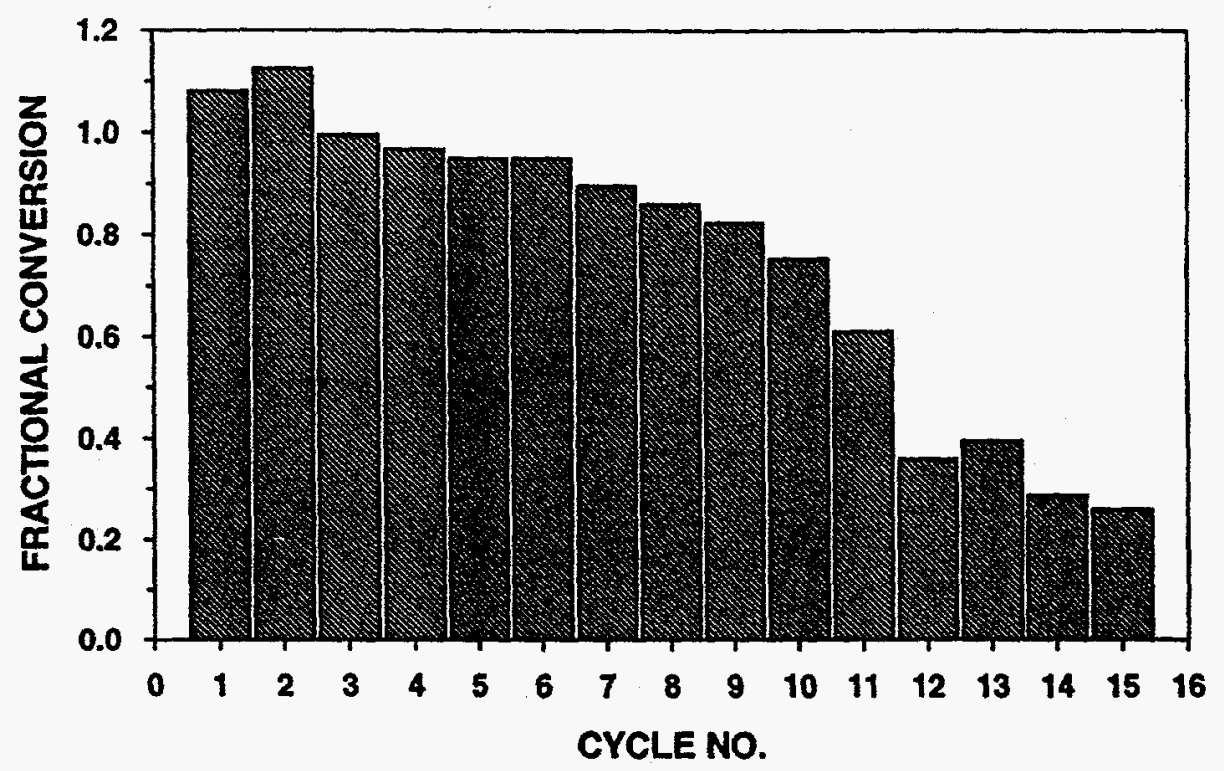

Figure 10. Conversions for sorbent IGTSS-1 AT $350^{\circ} \mathrm{C}$ 


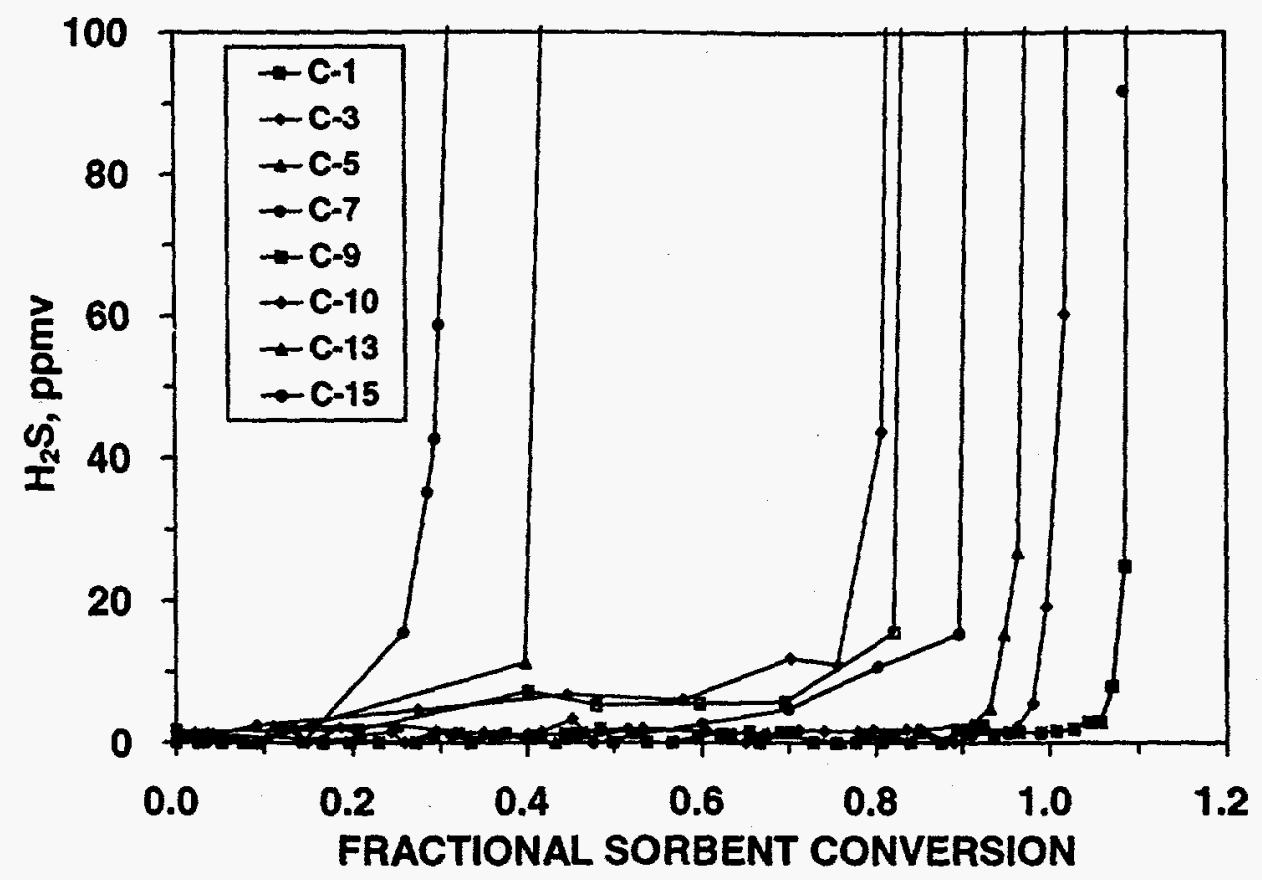

Figure 11. $\mathrm{H}_{2} \mathrm{~S}$ breakthrough curves for sorbent IGTSS-1 AT $350{ }^{\circ} \mathrm{C}$

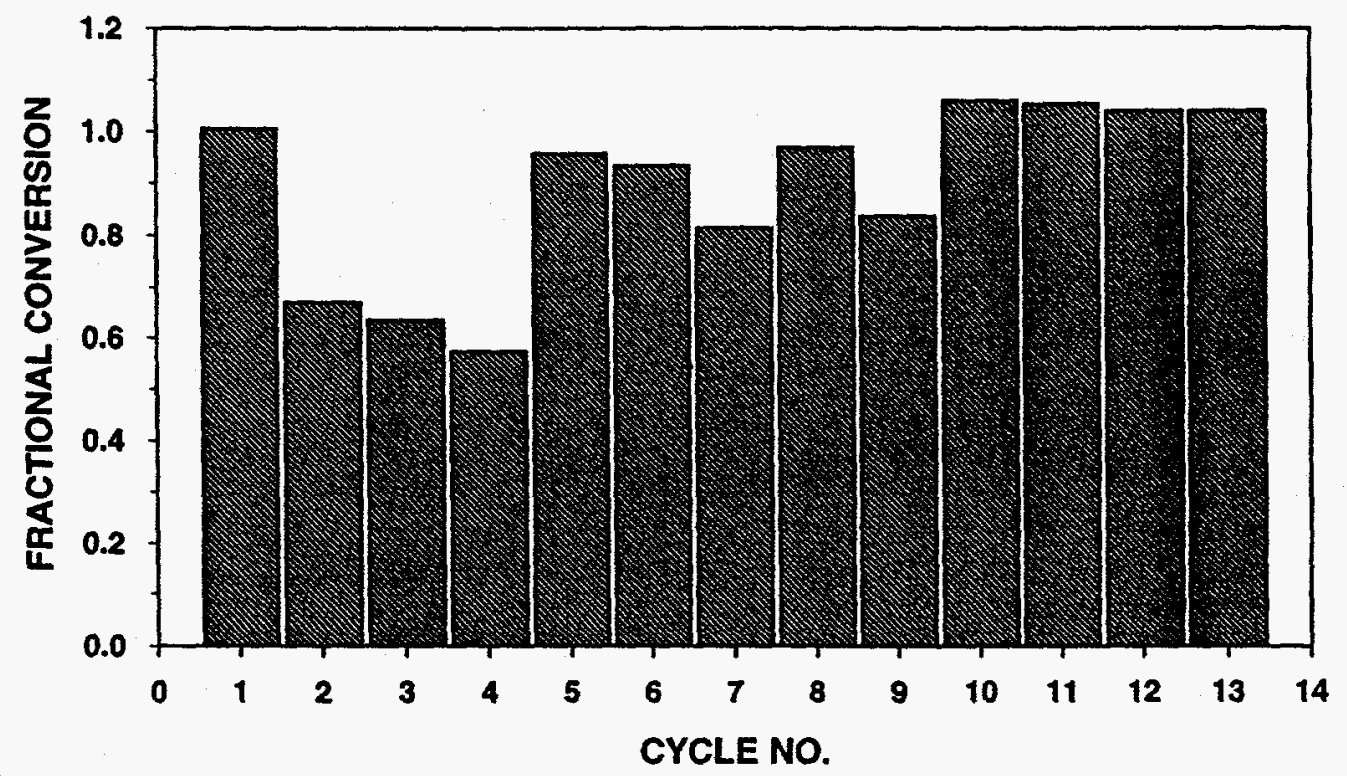

Figure 12.- Conversions for sorbent IGTSS-11 AT $450^{\circ} \mathrm{C}$ 


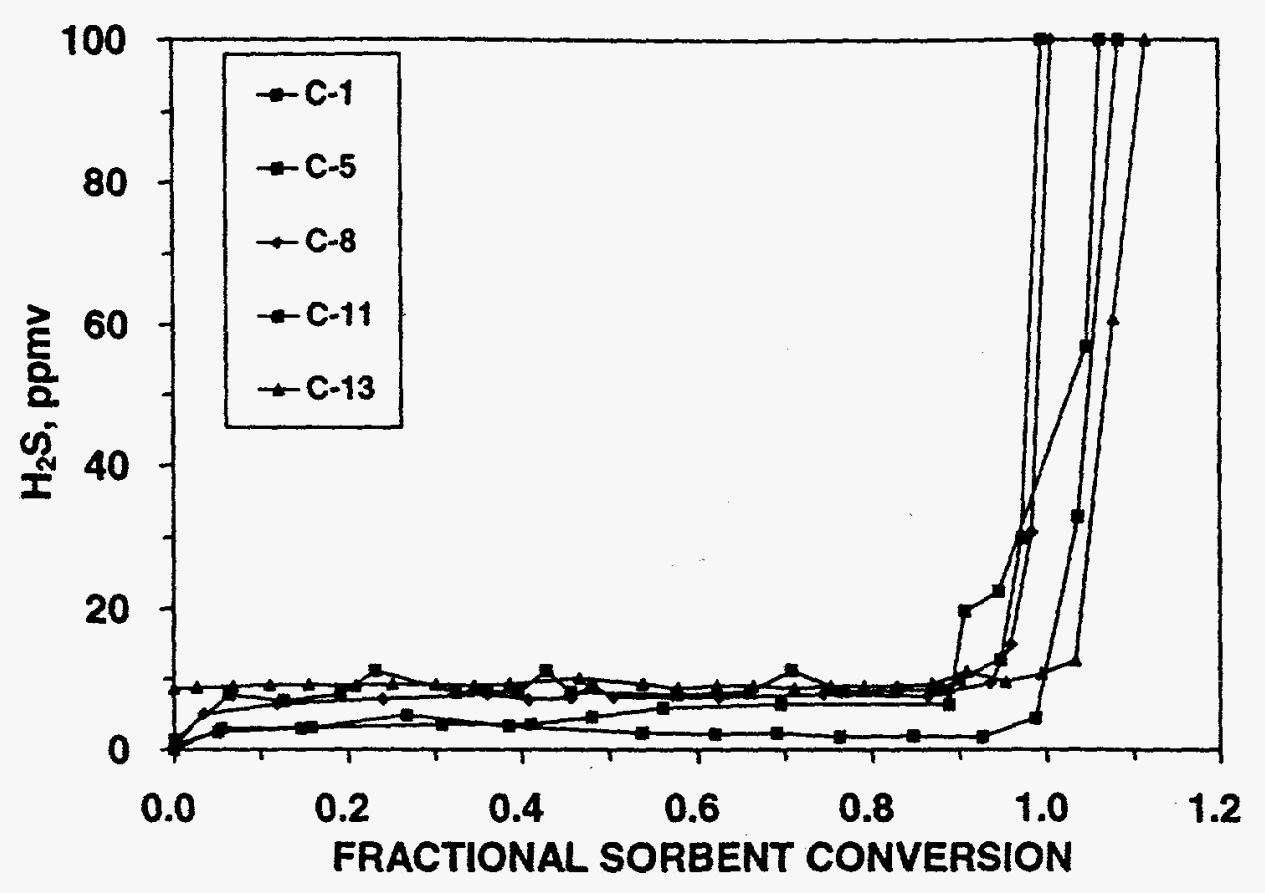

Figure 13. $\mathrm{H}_{2} \mathrm{~S}$ breakthrough curves for sorbent IGTSS-11 AT $450^{\circ} \mathrm{C}$

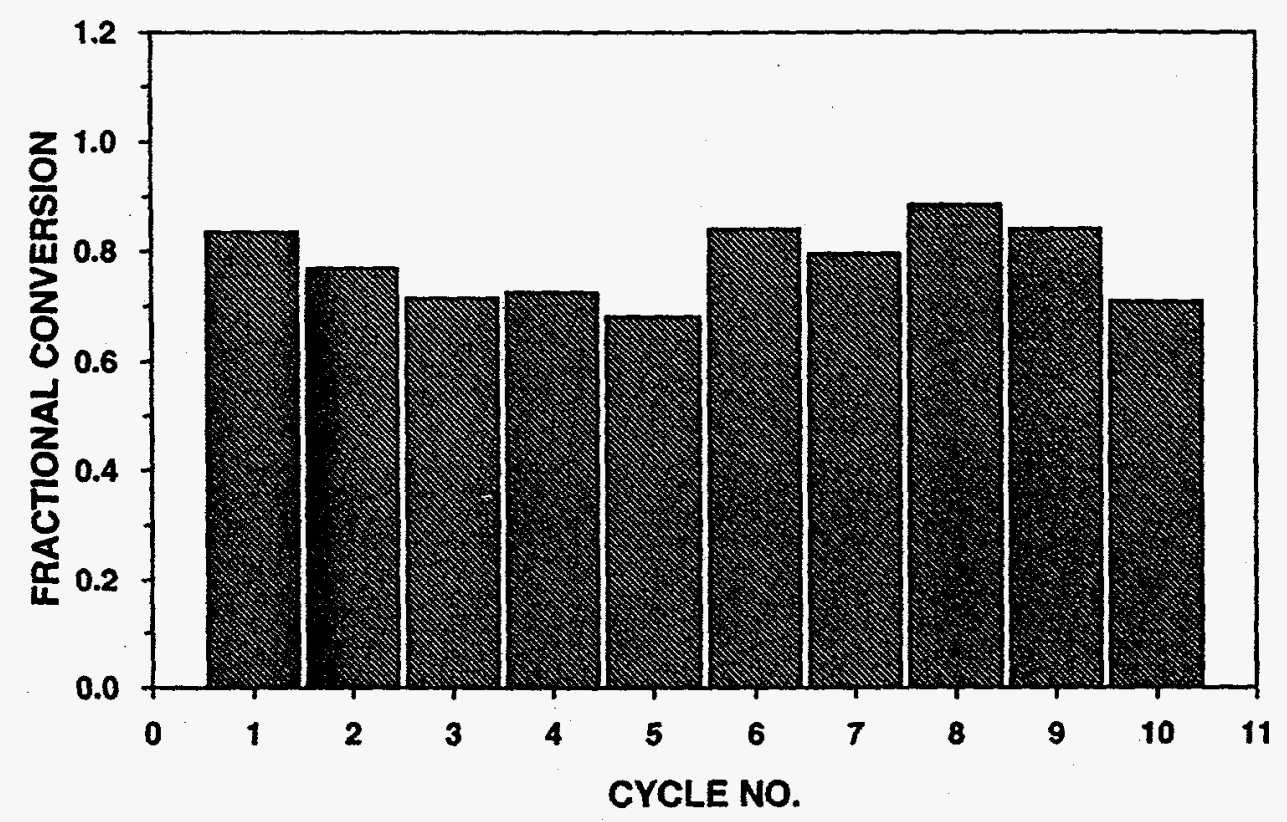

Figure 14. Conversions for sorbent IGTSS-6 AT $350^{\circ} \mathrm{C}$ 


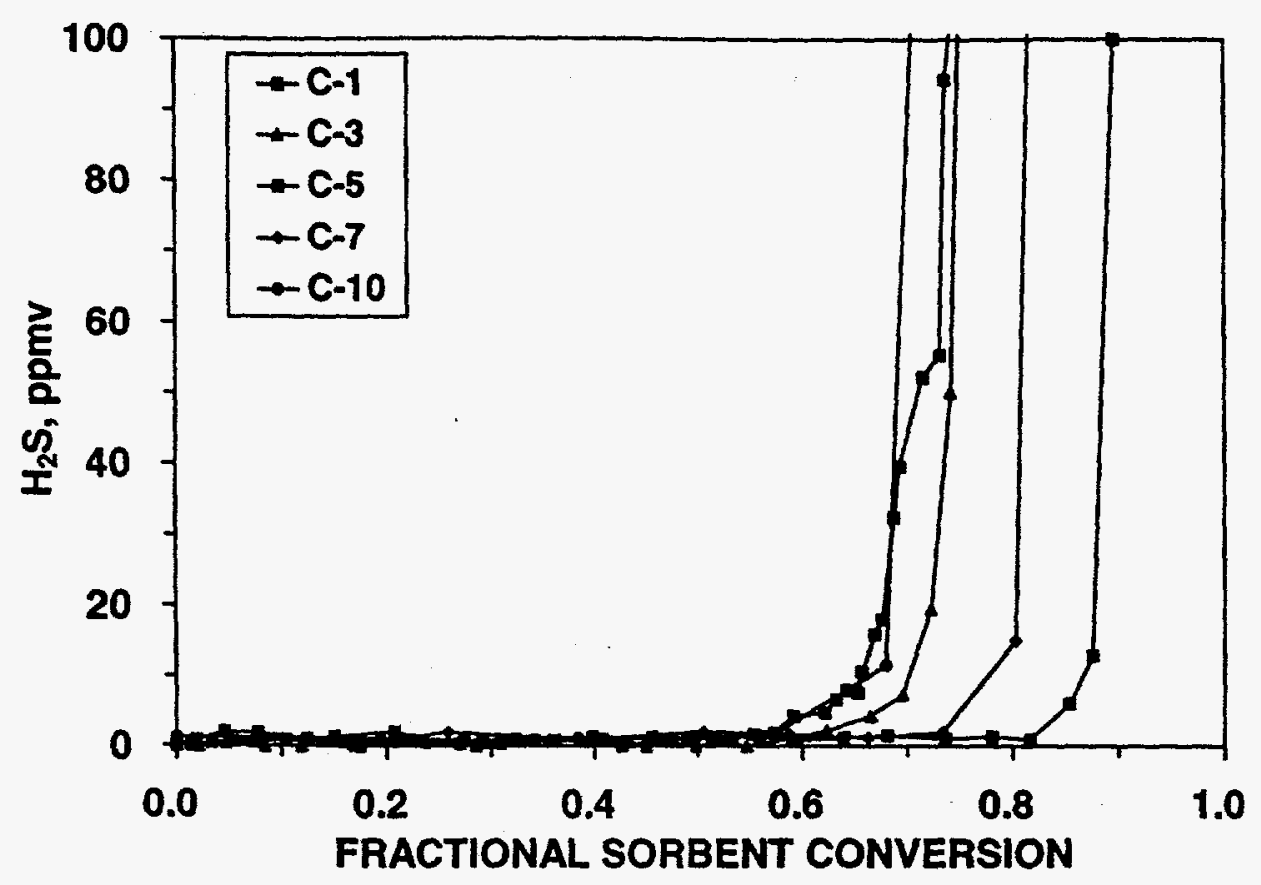

Figure 15.- $\mathrm{H}_{2} \mathrm{~S}$ Breakthrough curves for sorbent IGTSS-6 AT $350^{\circ} \mathrm{C}$

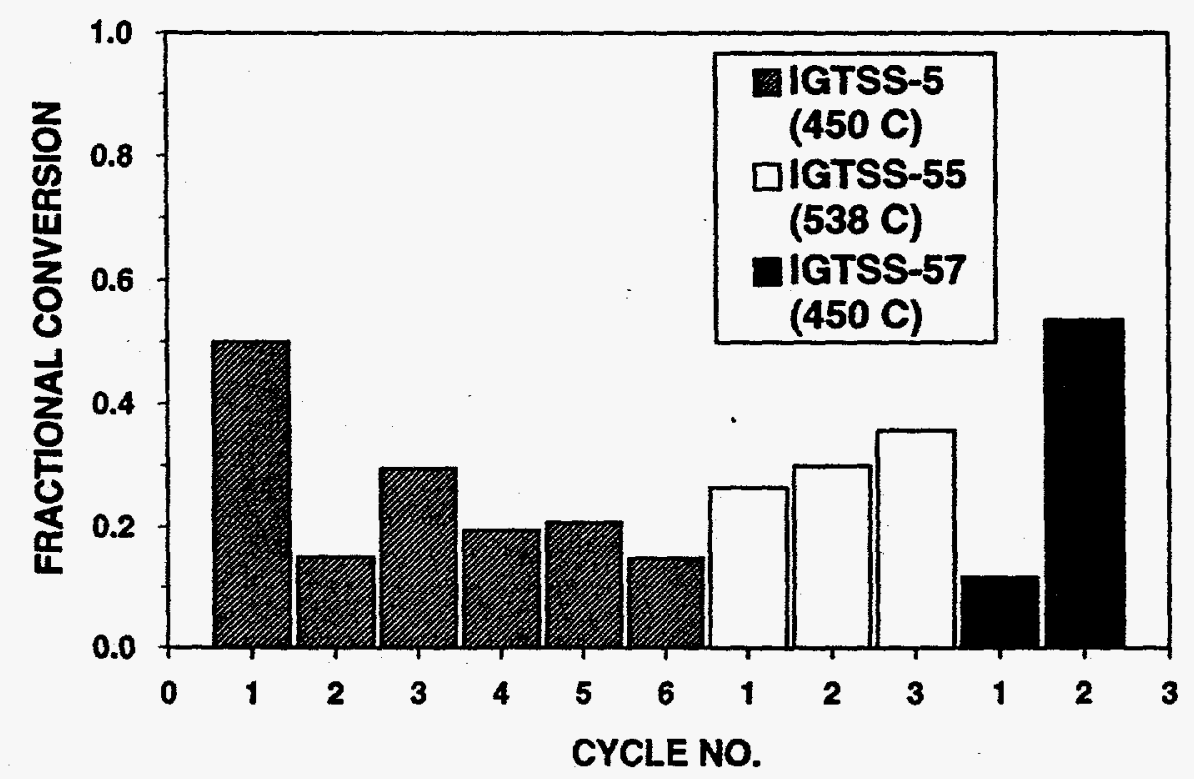

Figure 16. Conversions for sorbents with higher theoretical sulfur capacities 


\section{Task 3 -Provision of Bench-Scale Reactor}

Modifications to the existing bench-scale units at GE-CRD and IGT were conducted during the current reporting period. Several expendable and non-consumable items were purchased for use in sorbent screening or bench-scale testing at GE-CRD and IGT.

\section{Task 4 - Bench-Scale Testing}

\section{Task 5 - Sorbent Cost Assessment}

No effort has been spent during the current reporting period.

\section{Task 6 - Topical Report}

No effort has been spent during the current reporting period.

\section{Task 7 - Market Plan}

No effort has been spent during the current reporting period.

\section{Task 8 - Long-Term Testing (Optional)}

No effort has been spent during the current reporting period. 


\section{REFERENCES}

1. "MERC - Hot Gas Cleanup Process," Final Report, MERC/SP-78/2, Morgantown, W.V., 1978.

2. Joshi, D., Olson, T. H., Hayes, M. L. and Shah, "Hot Low-Btu Producer Gas Desulfurization in Fixed-Bed of Iron Oxide-Fly Ash," APCI Final Report to DOE, Contr. No. FE-77-2757-3, 1979.

3. Tamhankar, S. S., Hasatani, M. and Wen, C. Y., Chem. Eng. Sci. 36, 1181-1191 (1981).

4. Grindley, T. and Steinfeld, G., "Development and Testing of Regenerable Hot Coal Gas Desulfurization Sorbents," Final Report No. DOE/MC/16545-1125, 1981.

5. Jalan, V. and Wu, D., "High Temperature Desulfurization of Fuel Gases for Molten Carbonate Fuel Cell Power Plants," Paper presented at the National Fuel Cell Seminar, San Diego, CA, July 14-16, 1980.

6. Lew, S., "High-Temperature Regenerative $\mathrm{H}_{2} \mathrm{~S}$ Removal by $\mathrm{ZnO}-\mathrm{TiO}_{2}$ Systems," M.S. Thesis, Massachusetts Institute of Technology, January 1987.

7. Flytzani-Stephanopoulos, M. et al, Final Report to DOE, DOE/MC22193-2582, October 1987.

8. Lew, S., Jothimurugesan, K. and Flytzani-Stephanopoulos, M., Ind. Eng. Chem. Res. 28 , 535 (1989).

9. Westmoreland, P. R., Gibson, J. B. and Harrison, D. P., Env. Sci. Tech. 11 (5), 488 491 (1977).

10. Grindley, T. and Steinfeld, G., "Zinc Ferrite as Hydrogen Sulfide Absorbent," 3rd Ann. Contr. Mtg. on Contaminant Control in Coal-Derived Gas Streams, Rp. No. DOE/METC/84-6, 1983.

11. Anderson, G. L. et al., "Development of Hot Gas Cleanup System for Integrated Coal Gasification/Molten Carbonate Fuel Cell Plants," Final Report, No. DOE/MC/19403-1816, 1985.

12. Jalan, V. (Giner, Inc.), Final Report, DOE/MC/16021-1486, 1983. 
13. Flytzani-Stephanopoulos, M., Tamhankar, S. S., Sharma, P. K. and Gavalas, G. R., "Novel Sorbents for High-Temperature Regenerative $\mathrm{H}_{2} \mathrm{~S}$ Removal," Jet Propulsion Laboratory Final Report No. DOE/MC/20417-1898, October 1985.

14. Tamhankar, S. S., Bagajewicz, M., Gavalas, G. R., Sharma, P. K. and FlytzaniStephanopoulos, M., Ind. Eng. Chem. Proc. Des. Dev. 25, 429-437 (1986).

15. Flytzani-Stephanopoulos, M. et al., "High-Temperature Regenerative Removal of $\mathrm{H}_{2} \mathrm{~S}$ by Porous Mixed Oxide Sorbents," ACS Div. Fuel Chem. Preprints 30, 16-25 (1985).

16. Focht, G. D., Ranade, P. V., Harrison, D. P., "High-Temperature Desulfurization Using Zinc Ferrite: Reduction and Sulfidation Kinetics," Chemical Engineering Science, 43, (11) 3005-3013, 1988.

17. Smith, K. J., Haldipur, G. B. and Lucas, J. L., "KRW Process Development Coal Gasification/Hot Gas Cleanup," Proceedings, 7th Ann. Gasification and Gas Stream Cleanup Systems Contr. Rev. Mtg. DOE/METC-87/6079, 2, 668, June 1987.

18. Wu, T. C., Kassman, J. S. and Robin, A. M., "Integration and Testing of Hot Desulfurization and Entrained Flow Gasification for Power Generation Systems," Proceedings of 9th Ann. Gasification and Gas Stream Cleanup Systems Contr. Rev. Mtg., Morgantown, WV, June 1989, DOE/METC-89/6107, 1, 25-36.

19. Grindley, T. and Goldsmith, H., "Development of the Ferrite Desulfurization Sorbents for Large-Scale Testing," AIChE 1987 Annual Meeting, New York, November 15-20, 1987; Session 114D: Control of Hydrogen Sulfide From Hot Coal-Derived Gases.

20. Gavalas, G. R., Patrick, U., Jothimurugeson, Kandaswami, FlytzaniStephanopoulas, Maria, "High-Temperature Sulfidation-Regeneration of CuO$\mathrm{Al}_{2} \mathrm{O}_{3}$ Sorbents," Ind. Eng. Chem. Res., 28, $931-940$ (1989).

21. Flytzani-Stephanopoulas, Maria, Gavalas, George, R., Tamhankar, Statish, S., Sharma, Pramod, "Novel Sorbents for High-Temperature Regenerable $\mathrm{H}_{2} \mathrm{~S}$ Removal," METC, 1985.

22. Gangwal, S. K., Harkins, W. M., Stronger, J. M., Bossart, S. J., "Testing of Novel Sorbents for $\mathrm{H}_{2}$ Removal From Coal Gas," Environmental Progress, $\underline{8}$, (1) 26 (1989).

23. Gangwal, Santosh, K., Dorchak, Thomas, P., "Direct Sulfur Recovery Process for Elemental Sulfur Recovery from Gas," Research Triangle Institute. 
24. Flytzani-Stephanopoulos, M., Lew, S. and Sarofim, A. F., "Mechanistic and Kinetic Studies of High-Temperature Coal Gas Desulfurization Sorbents," Quarterly Report to DOE/PETC, DOE/PC88927-1, December 1988.

25. Flytzani-Stephanopoulos, M., Lew, S. and Sarofim, A. F., "Hot Gas Desulfurization by Zinc Oxide-Titanium Dioxide Regenerable Sorbents," ACS - Division of Fuel Chemistry Preprints of Papers. Presented at 199th ACS Nat'l Mtg., Boston, MA, Vol. 35 (1), p. 77, April 1990.

26. Patrick, V., Gavalas, G. R., Flytzani-Stephanopoulos, M. and Jothimurugesan, K., Ind. Eng. Chem. Res. 28, 931-940, 1989.

27. "Desulfurization of Hot Coal Gas in Fluidized-Bed With Regenerable Sorbents," J. Abbasian, K. Salo and W. Mojtahedi. Paper submitted for publication in Fuel Processing Technology, 1993.

28. "High Temperature Fuel Gas Desulfurization in Fluidized-Bed With Zinc Titanate," W. Mojtahedi, K. Salo, J. Abbasian, J. R. Wangerow and F. S. Lau. Paper presented at the AIChE Annual Meeting, St. Louis, 1993.

29. Abbasian, J., Hill, A. H., and Wangerow, J. R., "Development of Novel Copper Based Sorbent for Hot Gas Cleanup," Final Technical Report, September 1, 19909August 31, 1992, prepared by Institute of Gas Technology for Center for Research on Sulfur in Coal.

30. Abbasian, J., Rehmat, A., Stephanopoulous, M.F., and Hu, Z., "Development of Novel Copper-Based Sorbent for Hot Gas Cleanup." Paper presented at the 1992 AIChE Spring National Meeting, New Orleans, LA.

31. Abbasian, J., Hill, A. H., and Stephanopoulous, M.F., "Development of Novel Copper-Based Sorbent for Hot Gas Desulfurization." Paper presented at the AIChE 1993 Annual Meeting, St. Louis, Mo.

32. Anderson, G. A., et. al., "Development of a Hot Gas Cleanup System for Integrated Coal Gasification/Molten Carbonate Fuel Cell Power Plant," Final Report Prepared by Institute of Gas Technology for U.S. DOE/METC under Contract No. DE-AC2182MC19403, October 1985.

33. Bevan, S., D.J. Najewicz, E. Gal, A.H. Furman, R. Ayala, and A. Feitelberg. 1994. Integrated Operation of a Pressurized Gasifier, Hot Gas Desulfurization System and Turbine Simulator. In Proceedings of the Coal-Fired Power Systems $94-$ Advances in IGCC and PFBC Review Meeting, p. 222. DOE/METC-94/1008. NTIS/DE94012252. Springfield, Va.: National Technical Information Service.

34. Ayala, T. Chuck, E. Gal, and R.P. Gupta. 1994. Development of High Temperature Desulfurization Sorbents for Moving-Bed Systems. In Proceedings of the Coal- 
Fired Power Systems 94-Advances in IGCC and PFBC Review Meeting, p. 637. DOE/METC-94/1008. NTIS/DE94012252. Springfield, Va.: National Technical Information Service. 


\section{Appendix A: Phase Stability Diagrams for Various Metals}

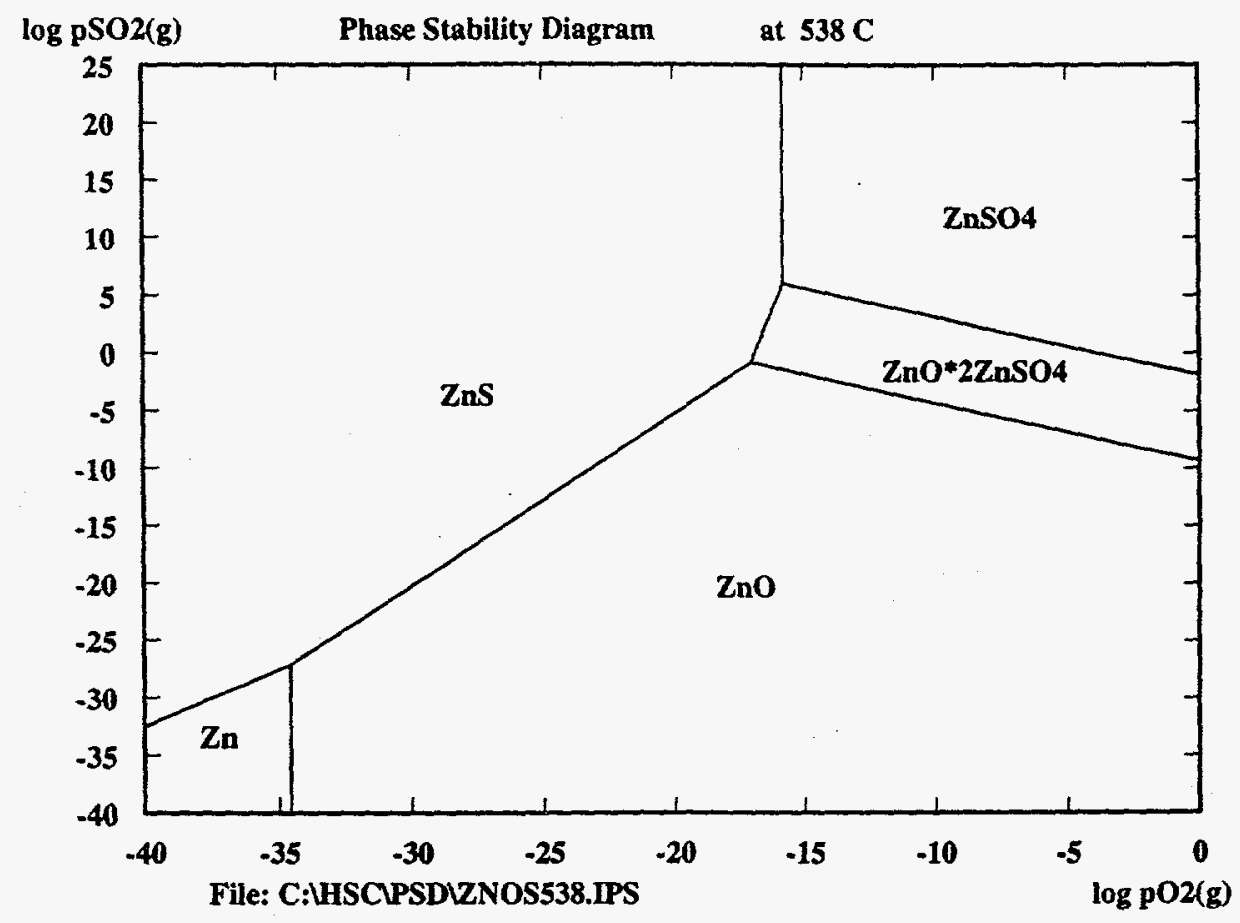

Figure A-1.- Phase Stability diagram for the system $\mathrm{Zn}-\mathrm{S}-\mathrm{O}$ at $538^{\circ} \mathrm{C}\left(1000{ }^{\circ} \mathrm{F}\right)$

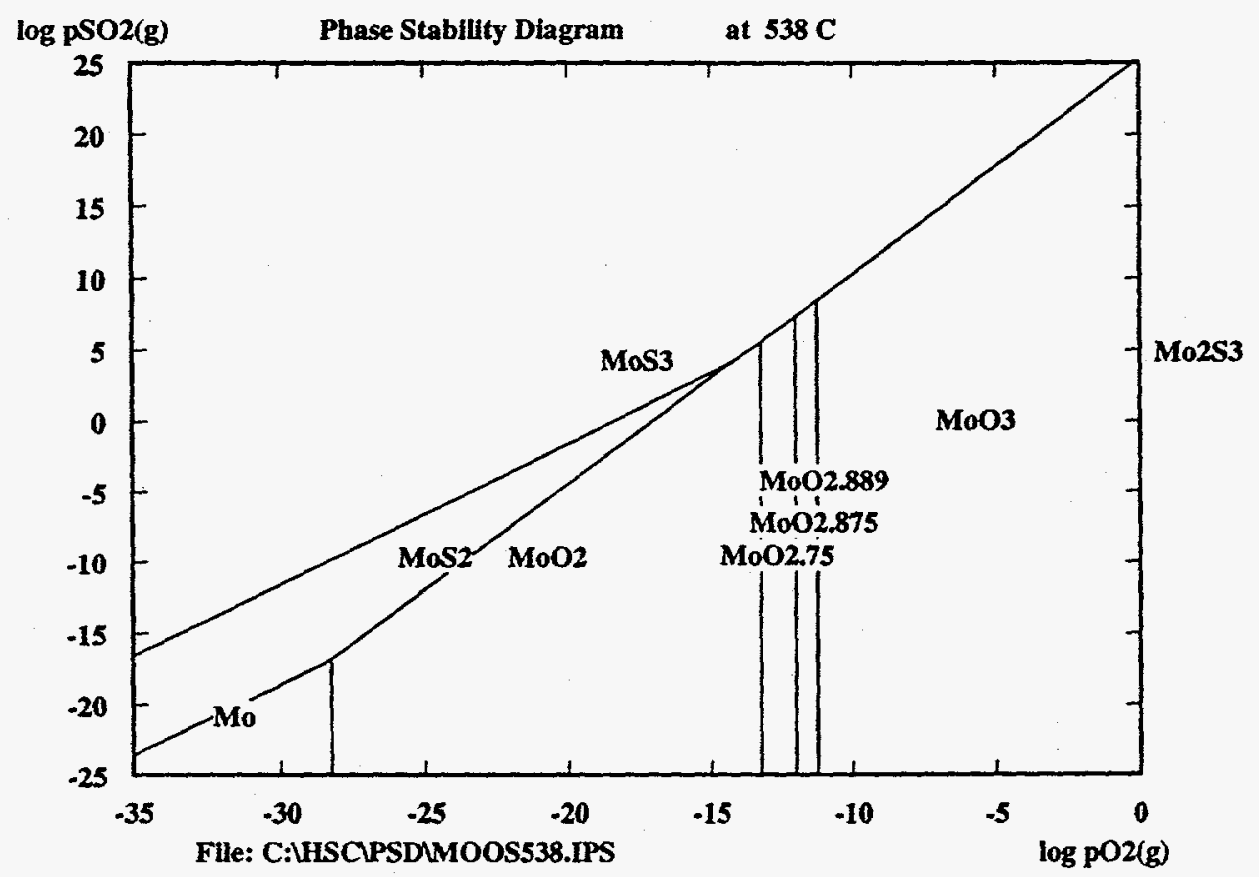

Figure A-2.- Phase Stability diagram for the system Mo-S-O at $538^{\circ} \mathrm{C}\left(1000^{\circ} \mathrm{F}\right)$ 


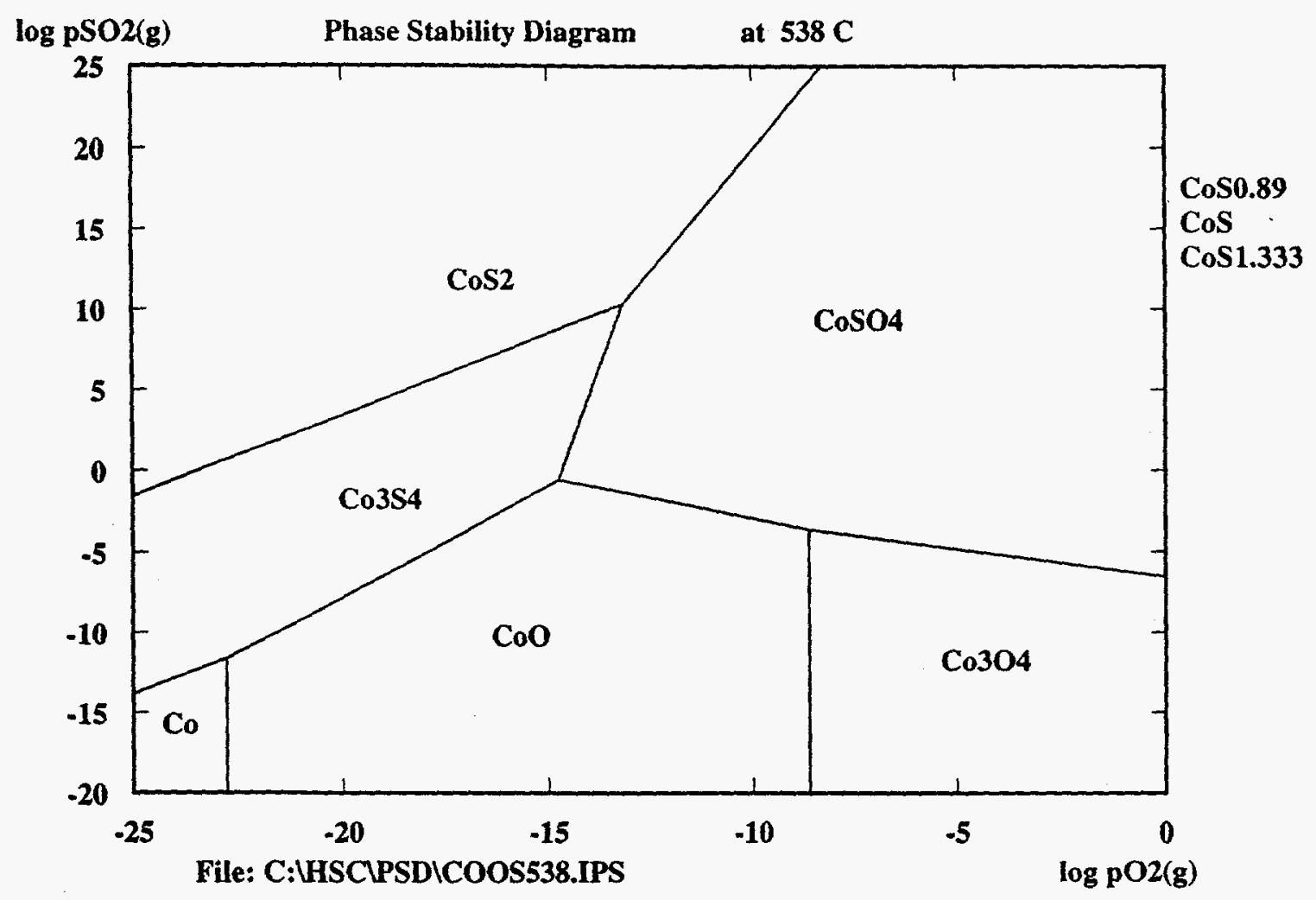

Figure A-3.- Phase Stability diagram for the system Co-S-O at $538^{\circ} \mathrm{C}\left(1000{ }^{\circ} \mathrm{F}\right)$

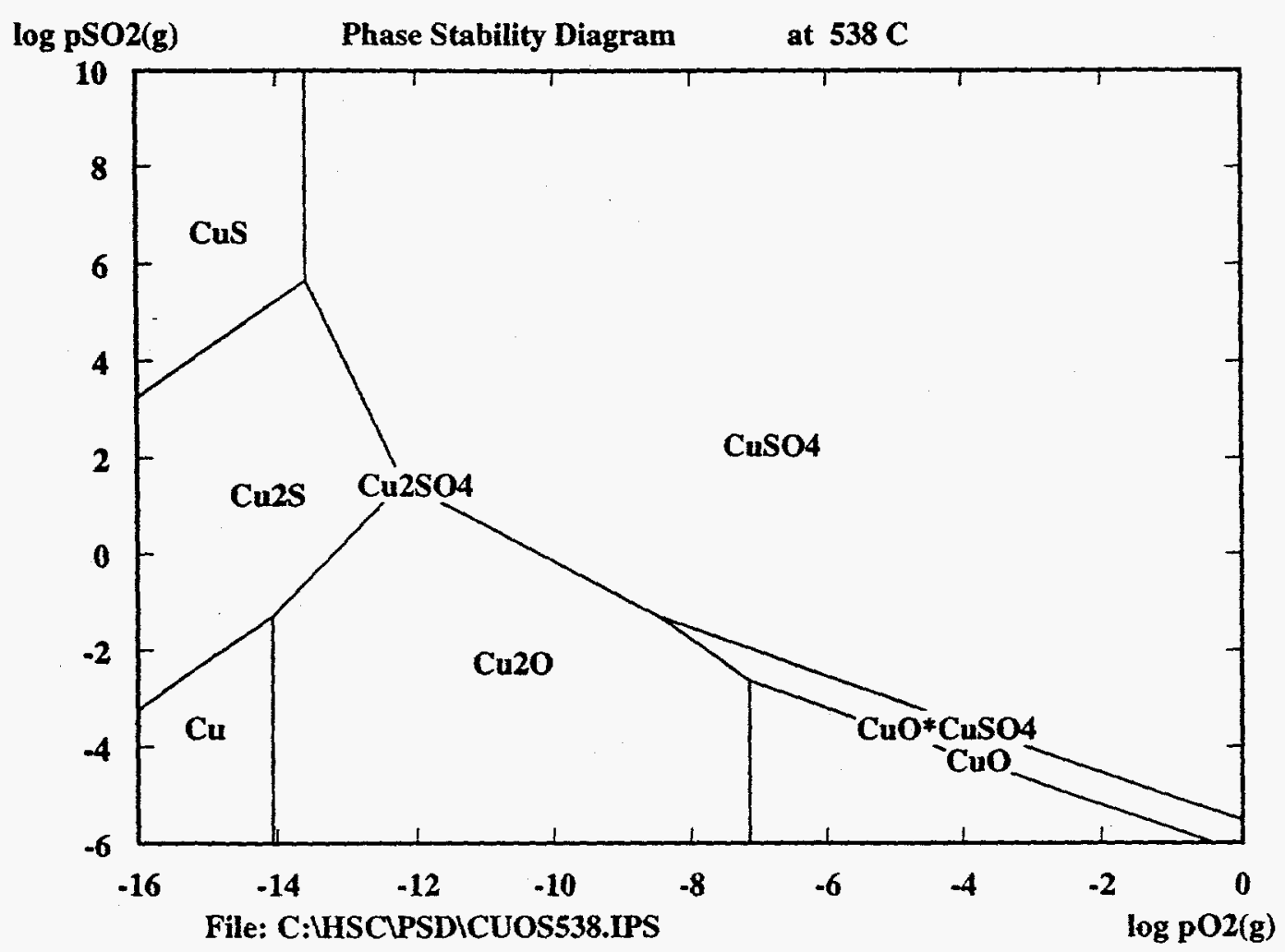

Figure A-4.- Phase Stability diagram for the system Cu-S-O at $538^{\circ} \mathrm{C}\left(1000^{\circ} \mathrm{F}\right)$ 